\title{
Convergence and Divergence in post-Cold War British, French and German Military Reforms: Between International Structure and Executive Autonomy
}

Post-Cold War military reforms in Britain, France and Germany have been characterized by patterns of convergence in the objectives, instruments and institutional forums of defense policy, but by divergence in temporality. These patterns of convergence and divergence cannot be fully explained by cultural approaches. Neither can they be explained solely by a focus on the role of 'international structure', as neo-realism posits, although the post-Cold War distribution of capabilities is driving Britain, France and Germany towards policy convergence. Instead the analysis builds upon the insights of neoclassical realism and its emphasis upon 'state power' by demonstrating the important intervening role played by domestic material power relationships in incentivizing figures within the core executive to respond to systemic power shifts. The article argues that in Britain and France 'executive autonomy' in defense policy, resulting from the unitary state, weak linkages between defense and social policy subsystems and formal powers of the core executive in defense has allowed policy leaders to focus on the 'national interest' and convergence with 'systemic imperatives'. In Germany the federal system and linkages between social and defense policy circumscribed 'executive autonomy' in defense policy and incentivized an acute concern within the core executive about the domestic political ramifications of convergence with systemic imperatives, leading to the temporal management of reform, producing short-medium term policy stasis. Culture emerges not so much as a cause of action as instrumental and a resource for policy leaders in the domestic political and temporal management of reform.

This article examines patterns of convergence and divergence in post-Cold War British, French and Germany military reforms and finds that it is possible to identify increasing levels of convergence in the objectives, instruments and institutional forums of defense policy. However, it uncovers significant divergence in the temporality of reform processes. ${ }^{1}$ The study argues that these patterns of convergence/divergence cannot be explained through a focus on the mediating role played by 'national strategic cultures' 'culturally-bounded' and 'institutionally-embedded' norms that 'predispose societies in general and political elites to certain patterns of behavior'. 2 They cannot be understood

Tom Dyson is a Lecturer in International Security at Department of Political, International and Policy Studies at the University of Surrey.

I thank Major Stephanie Ahern, Professor Theo Farrell, Dr. Theodore Konstadinides, Professor Mark Olssen and the two anonymous referees for Security Studies for their detailed comments. Earlier versions of this paper were presented at the International Studies Association Annual Convention, San Francisco, 2008; Political Studies Association Annual Conference, Swansea, 2008 and the 2007 University Association of Contemporary European Studies Annual Conference, Portsmouth, 2007.

${ }^{1}$ The author disaggregates temporality according to the three categories outlined by Andreas Schedler and Javier Santiso: temporal location (when reform takes place); sequence (in what order reform is enacted) and pace (the speed at which reform takes place). See Andreas Schedler and Javier Santiso, "Democracy and Time: An Invitation,” International Political Science Review 19, no.1 (winter 1998): 5-18.

2 See Thomas Berger, Cultures of Anti-Militarism: National Security Cultures in Germany and Japan (Baltimore: John Hopkins University Press, 1998); John S. Duffield, World Power Forsaken: Political Culture, International Institutions and German Security Policy After Unification (Stanford: Stanford University Press, 1998), 27. 
through an examination of the role of 'political/norm entrepreneurs' within the core executive or actors within the wider security policy subsystem ${ }^{3}$, in reshaping the three layers of belief systems (peripheral, operational and central beliefs) of which strategic cultures are composed. ${ }^{4}$ Nor is an examination of the impact of civil-military relations on the organizational culture of defense ministries and military establishments a sufficient account of policy change. 'Culture' emerges not so much as a cause of action as a tool, resource and instrument for policy leaders concerned with the domestic political and temporal management of reform.

The analysis finds that 'international structure' is the key source of change and convergence in the objectives, instruments and institutional forums of defense policy. ${ }^{6}$ However, neo-realist accounts neglect the impact of domestic political factors in constraining the autonomy of the core executive to respond to systemic power shifts over the short-medium term and cannot adequately account for temporal divergence in military reform amongst states of broadly comparable relative material power capabilities and 'external vulnerability'. 'Hence neoclassical realism, that emphasizes the primacy of 'international structure', but also integrates the intervening role played by 'unit-level variables', such as domestic power relationships and strategic leadership, emerges as the most convincing account of convergence/divergence in military reform. ${ }^{8}$

\footnotetext{
${ }^{3}$ A policy subsystem refers to a 'group of people and or organizations interacting regularly over periods of a decade or more to influence policy formulation and implementation within a give policy area/domain'. See Paul A. Sabatier and Hank Jenkins-Smith, "The Advocacy Coalition Framework: An Assessment", in Theories of the Policy Process, ed. Paul A. Sabatier (Boulder: Westview, 1999), 135.

${ }^{4}$ Central beliefs are 'abstract beliefs and basic assumptions about the international system...rarely questioned and stable'; 'operational beliefs' relate to the 'efficacy of different policy instruments and strategies', whilst 'peripheral beliefs' are 'more transient and concern concrete issues and objects'. See Anja Dalgaard-Nielsen, Germany, Pacifism and Peace-Enforcement (Manchester: Manchester University Press, 2006), 13. Kerry Longhurst terms the three layers of beliefs of which strategic culture are composed 'foundational elements', 'security policy standpoints' and 'regulatory practices'. See Kerry Longhurst, Germany and the Use of Force: The Evolution of German Security Policy: 1990-2003 (Manchester: Manchester University Press, 2004), 17. Paul A. Sabatier also argues that advocacy coalitions are structured by three layers of beliefs: 'deep core', 'policy core' and 'secondary aspects'. See Sabatier, "The Advocacy Coalition Framework: An Assessment”, 113.

${ }^{5}$ Elizabeth Kier, Imagining War: French and British Military Doctrine Between the Wars (Princeton: Princeton University Press, 1997), 4.

${ }^{6}$ On international structure and 'clustered convergence', see Joao Resende-Santos, Neoeralism, States and the Modern Mass Army (Cambridge: Cambridge University Press, 2007), 78. On "international structure and convergence' see also Galia Press-Barnathan, "Managing the Hegemon: NATO Under Unipolarity," Security Studies 15, no.2 (spring 2006): 271-309; Adrian Hyde-Price, European Security in the $21^{\text {st }}$ Century: The Challenge of Multi-Polarity (Abingdon: Routledge, 2007); Seth Jones, The Rise of European Security Cooperation (Cambridge: Cambridge University Press, 2007); Barry R. Posen, The Sources of Military Doctrine: Britain, France and German Between the Wars (Ithaca: Cornell University Press, 1984); Kenneth N. Waltz, Theory of International Politics (Reading MA: Addison Wesley, 1979), 127.

${ }^{7}$ Barry R. Posen (2006: 156) classifies Britain, France and Germany second-rank, 'consequential' states, of similar relative material power, which combined with their similar geographical location leads to a comparable level of 'external vulnerability'. See Barry Posen, "The European Security and Defence Policy: Response to Uni-polarity," Security Studies 15, no.2 (spring 2006): 156. On 'external vulnerability' see Jeffrey W. Taliaferro, "State Building for Future Wars: Neoclassical Realism and the Resource-Extractive State," Security Studies 15, no.3 (summer 2006): 467; 479.

${ }^{8}$ On Neoclassical Realism see: Gideon Rose, "Neoclassical Realism and Theories of Foreign Policy," World Politics 51, no.3 (autumn 1998): 144-72; Sten Rynning, "Shaping Military Doctrine in France: Decisionmakers Between International Power and Domestic Interests," Security Studies 11, no.2 (winter
} 
As Zakaria argues: 'Foreign policy is made not by the nation as a whole but by its government. Consequently what matters is state power, not national power. State power is that portion of national power the government can extract for its purposes and reflects the ease with which central decision-makers can achieve their ends'. Taliaferro highlights how states which are confronted with the same threat vary in their ability to extract and mobilize resources from domestic society: unit-level variables - state institutions, ideology and nationalism - affect whether and when states choose innovation, emulation or the continuation of existing military strategies. ${ }^{10}$ This article responds to the research agenda outlined by Sten Rynning ${ }^{11}$, and Gideon Rose ${ }^{12}$ by focusing specifically on the impact of different state structures and domestic material power relationships on the extraction and deployment of national power by state leaders and by testing neoclassical realism against cultural approaches to strategic adjustment.

In his study of French military reform, Rynning posits that the key unit-level variable in explaining temporal divergence with systemic power shifts is the ability of policy leaders to successfully manage domestic reform processes. ${ }^{13}$ However, whilst it is important to analyze the impact of specific instances of policy leadership, in order to fully understand the root causes of temporal divergence, we must look instead to the domestic material incentives that determine the initial choice of leadership role. The level of 'executive autonomy' in defense policy, resulting from the institutional structure of the state (the degree of centralization), the formal constitutional powers of the core executive over defense policy and nested and interlinked policy subsystems (defense/budgetary/social policy) incentivizes or discourages political entrepreneurship by policy leaders on behalf of 'third-order' ${ }^{\text {'4 }}$ change and the 'timely' translation of systemic power shifts into military reform ${ }^{15}$.

The article argues that high levels of "executive autonomy" ${ }^{16}$ in defense policy

2001/02): 85-116; Taliaferro, "Neoclassical Realism and the Resource Extractive State". This contrasts to Innenpolitik approaches, which attach causal weight to domestic politics in driving foreign and defense policy. See Eckart Kehr, Battleship Building and Party Politics in Germany 1894-1901 (Chicago: University of Chicago Press, 1973); Jack L. Snyder, Myths of Empire: Domestic Politics and International Ambition (Ithaca: New York, 1991); Fareed Zakaria, "Realism and Domestic Politics: A Review Essay," International Security 7, no.1 (spring 1991): 180-81.

${ }^{9}$ Fareed Zakaria, From Wealth to Power: The Unusual Origins of America's World Role (Princeton: Princeton University Press, 1998), 9.

${ }^{10}$ Taliaferro, "Neoclassical Realism and the Resource-Extractive State," 465-68.

${ }^{11}$ Rynning, "Shaping Military Doctrine in France: Decision Makers Between International Power and Domestic Interests," 116.

${ }^{12}$ Rose, "Neoclassical Realism and Theories of Foreign Policy," 169.

${ }^{13}$ Rynning, "Shaping Military Doctrine in France: Decision Makers Between International Power and Domestic Interests."

${ }^{14}$ Peter Hall defines three levels of policy change: 'first-order change' in which the settings of policy instruments are changed, while the overall goals and instruments of policy remain constant; second-order change in which both the instruments and settings of policy are altered, while the goals of policy remain unchanged and finally 'third-order change', in which all three components of policy - settings, instruments and the hierarchy of goals - are transformed. See Peter Hall, "Policy Paradigms, Social Learning and the State: The Case of Economic Policy Making in Britain," Comparative Politics 25, no.3 (autumn, 1993): 278-9.

${ }^{15}$ Rynning, "Shaping Military Doctrine in France: Decision Makers Between International Power and Domestic Interests," 115-16.

${ }^{16}$ It is important to note that periods of 'cohabitation' in France can lower 'executive autonomy' and create incentives for the temporal management of reform. 
help explain the temporal location, sequencing and pace of military reform in the UK and France. ${ }^{17}$ However, the case of Bundeswehr (German armed forces) reform highlights that whilst policy over the long-run is dictated by the threats and opportunities presented by the international system, deficits in 'executive autonomy' can lead to the active promotion of 'stasis' and 'first-order change' in military reform over the short-medium term. Within such a context 'culture' is used selectively by policy leaders as a resource with which to legitimate policy stasis as part of the domestic political and temporal management of reform. ${ }^{18}$ This preoccupation with 'balancing domestic power' ${ }^{\text {,19 }}$ and the domestic political ramifications of convergence with systemic change, rather than the 'national interest', also impacts upon the anchoring of defense policy within EU/NATO 'allied cooperation', determining whether this will reflect systemic imperatives or domestic interests over the short-medium term. ${ }^{20}$ Hence 'executive autonomy', rather than strategic culture, or specific instances of policy leadership, forms the decisive causal variable in explaining temporal divergence in military reform.

The article begins by briefly examining the empirical evidence of convergence in British, French and German defense policy. It proceeds by outlining the core premises of cultural and realist approaches to convergence and by testing their utility through case studies of the reform processes in these three states.

\section{Patterns of Convergence and Divergence in Military Reform}

According to Bennett, policy convergence represents 'a process of 'becoming' rather than a condition of 'being' alike...there must be movement over time to some common point. In comparative research...the essential theoretical dimension is temporal rather than spatial' ${ }^{21}$ Knill offers a more substantive definition, arguing that policy convergence is 'any increase in the similarity between one or more characteristics of a certain policy... across a given set of political jurisdictions... over a given period of time.

\footnotetext{
${ }^{17}$ Although, as the analysis will also demonstrate, the opacity of systemic imperatives emerges as an important additional factor determining the initial short-term temporal lag between systemic power shifts and military reform in states with high levels of executive autonomy. Whilst the uncertainty is an inherent feature of the international system, the problem of imperfect information is magnified following a dramatic shift in the balance of capabilities. States, as rational actors, must become acquainted with the opportunities and constraints presented by their new strategic environment. See Hyde-Price, European Security in the $21^{\text {st }}$. Century: The Challenge of Multipolarity, 32. See also Robert Keohane on the 'rationality assumption' and realist thought: Robert Keohane, "Theory of World Politics", in Neo-realism and Its Critics, ed. Robert Keohane (New York: Columbia University Press, 1986), 167.

${ }^{18}$ On the temporal management of reform processes see: Tom Dyson, "German Military Reform 19982004: Leadership and the Triumph of Domestic Constraint Over International Opportunity," European Security 14, no.3 (autumn 2005): 361-86; Tom Dyson, The Politics of German Defence and Security: Policy Leadership and Military Reform in the post-Cold War Era (New York: Berghahn, 2008).

${ }^{19}$ On 'internal balancing' see: Rynning, "Shaping Military Doctrine in France: Decision Makers Between International Power and Domestic Interests," 90.

${ }^{20}$ Dyson, The Politics of German Defence and Security: Policy Leadership and Military Reform in the Post-Cold War Era, 148-82.

${ }^{21}$ Colin Bennett, "Review Article: What is Policy Convergence and What Causes It?" British Journal of Political Science 21, no. 2 (summer 1991): 19.
} 
Policy convergence thus describes the end result of a process of policy change towards some common point'. 22

Building upon these broad definitions this article distinguishes between convergence in British, French and German military reforms along four dimensions: defense policy objectives (territorial and alliance defense/low- medium- high-intensity expeditionary crisis-management operations); policy instruments (military structures and capabilities); the institutional forums within which defense policy is anchored (national strategic autonomy or the embedding of defense policy within the EU/NATO) and finally temporality (the temporal location, sequence and pace of reform).

During the Cold War West European militaries displayed strong convergence in policy objectives. The principles of deterrence and territorial/alliance defense stood at the center of British, French and German defense policy. Their policy instruments (armed forces) were also convergent, taking the form of mass armies, designed to resist a Warsaw Pact advance across the German plain (see table 1). Divergence was apparent in institutional forums: whilst Britain and Germany prioritized NATO, French defense policy, was characterized by the Gaullist principles of 'national sanctuary' and 'strategic autonomy', following its withdrawal from NATO's integrated military structures in 1966, leading to a 'semi-detached' defense policy. ${ }^{23}$ However, the end of the Cold War led to dramatic changes in the international security environment: a shift from a bi-polar to a uni-polar world, unilateral changes in U.S. behavior, the rise of new security threats and challenges such as failed states, humanitarian emergencies, international terrorism, organized crime and the proliferation of weapons of mass destruction (WMD). ${ }^{24}$ Within this changing context longer-tem convergence patterns in the objectives, instruments and institutional forums of British, French and German defense policy are evident.

Convergence in Objectives, Instruments and Institutional Forums; Divergence in Temporality

22 Christopher Knill, "Introduction: Cross National Policy Convergence: Concepts, Approaches and Explanatory Factors," Journal of European Public Policy 12, no.5 (winter 2005): 768.

${ }^{23}$ It is important to note that, despite French withdrawal from NATO's integrated military commands the Ailleret-Lemnitzer and Valentin-Feber Accords of 1966-97 outlined far-reaching French participation with NATO states in the context of European conflict. See Philip Gordon, A Certain Idea of France (Princeton: Princeton University Press, 1992; Anand Menon, "From Independence to Cooperation: France, NATO and European Security," International Affairs 71, no.1 (winter 1995): 19.

${ }^{24}$ On the core post-Cold War security threats identified by EU and NATO member states see: 'A Secure Europe in a Better World: European Security Strategy, 12 December 2003, pp.1-5 and The Riga Summit: A Reader's Guide, $6^{\text {th }}$ July, 2007, p.4. Although, as is recognized later on in the article, the objectivity of these security threats is challenged by the literatures on 'securitization' and 'strategic culture'. On securitization see: Thierry Balzacq, "The Three Faces of Securitization: Political Agency, Audience and Context," European Journal of International Relations 11, no.2 (spring 2005): 171-205; Barry Buzan, Ole Waever and Jaap de Wilde, Security: A New Framework for Analysis (Boulder: Lynne Rienner, 1998); Holger Stritzel, "Towards a Theory of Securitization: Copenhagen and Beyond," European Journal of International Relations 13, no.3 (summer 2007): 357-83. On strategic culture and the subjective and nationally-specific normative and discursive processes that determine whether issues are identified as security threats, national defense policy objectives, the appropriate policy instruments and capability investment see: Dalgaard-Nielsen, Germany Pacifism and Peace Enforcement; Longhurst, Germany and the Use of Force: The Evolution of German Security Policy: 1990-2003. 
Britain, France and Germany display increasing convergence in the objectives of defense policy, having transformed the core objectives of defense policy from territorial and alliance defense towards a new form of 'forward defense': low-medium and high intensity expeditionary crisis-management operations to deal with threats to international instability at their source. In this respect, all three states have undertaken convergence around the US model of expeditionary power projection, though with a stronger focus on low-medium intensity peacekeeping and post-conflict reconstruction operations. ${ }^{25}$

Both Britain and France have also successfully enacted reforms to their policy instruments, notably through the creation of 'Joint Reaction Forces', structured according to the principle of modularity and in the case of France, through the abolition of conscription in 1996. This mirrors the U.S. integration of naval, air and land power, allowing the global projection of force (as part of multilateral coalitions) in support of low, medium and high-intensity military operations, making these states cases of 'thirdorder change'. ${ }^{26}$ However, all three states have deviated from the centralization that has characterized U.S. Command Structures, by employing 'mission command', permitting greater flexibility in the conduct of military operations.

Yet, despite the development of a Joint Reaction Force and focus on NEC and Effects Based Operations since the 2003 VPR and 2006 Defence White Paper, Germany remains a case of 'second-order change'. German reforms have proposed only successive alterations to the 'settings' of the policy instrument. Transformation is hindered by the retention of conscription: 37,500 basic service conscripts and 21,600 extended service conscripts. ${ }^{27}$ This is not only a practical impediment to the development of an expeditionary capacity ${ }^{28}$, but also a financial burden at a time when funds are required for investment in capabilities to permit force projection, limiting Germany's ability to contribute to medium-high intensity operations. ${ }^{29}$

Capability investment evidences partial convergence with the US-led

\footnotetext{
${ }^{25}$ Timothy Edmunds, "What Are Armed Forces For? The Changing Nature of Military Roles in post-Cold War Europe," International Affairs 82, no. 6 (winter 2006): 1059/75; Anthony Forster, Armed Forces and Society in Europe (London: Palgrave Macmillan, 2005), 50; James Sperling, "Capabilities Gaps and Traps: Symptom or Cause of a Troubled Trans-Atlantic Relationship?" Contemporary Security Policy 25, no.3 (2004): 457-58.

${ }^{26}$ See Max Boot, "The New American Way of War," Foreign Affairs 82, no.4 (2003): 43 and Anthony King, "Towards a Transnational Europe: The Case of the Armed Forces," European Journal of Social Theory 8, no.3 (2005): 321-40. However, all three states are dependent upon the multilateral pooling of capabilities (particularly with U.S. and its command of the 'global commons', in order to deploy mediumhigh-intensity military power at the global level). See Edmunds, "What Are Armed Forces For? The Changing Nature of Military Roles in post-Cold War Europe," 1068; see also and Barry R. Posen, "Command of the Commons: The Military Foundations of U.S. Primacy," International Security 28, no.1 (summer 2003): 5-46.

${ }^{27}$ Soren Lungu, "Military Modernization and Political Choice: Germany and the US-Promoted Military Technological Revolution During the 1990s," Defence and Security Analysis 20, no.1 (spring 2004): 26172 .

${ }^{28}$ The 2006 German Defence White Paper recognizes that basic service conscripts will be unable to contribute to the 'reaction forces' or the 'stabilization forces'. See White Paper 2006 on German Security Policy and the Future of the Bundeswehr (Federal Ministry of Defence, 2006), 78-79.

${ }^{29}$ The 2003 reform reduced the Bundeswehr to 252,000 troops including 50,000 conscripts, capable of delivering 35,000 rapid reaction troops (high-intensity); a stabilization force of 70,000 (low-medium intensity) and 147,500 support/logistical forces.
} 
Revolution in Military Affairs. ${ }^{30}$ Crucially, reform in all three states does not evidence the 'technological determinism' that has been the defining feature of post-Cold War U.S. military reform. ${ }^{31}$ Britain, France and Germany have undertaken a more modest and selective emulation of the core concepts underpinning US 'transformation' (Network Centric Warfare (NCW) and Effects Based Operations (EBO)) ${ }^{32}$, in the form of Network Enabled Capability (NEC) and the Effects Based Approach to Operations (EBAO).

On the one hand, reforms to their capabilities, not least the acquisition of C4ISR and precision-guided munitions (PGM), reflects the desire to augment their capacity to undertake stand-off high-intensity warfighting operations against peer or near-peer competitors alongside the U.S. and/or each other though NATO and the EU (though only as part of multi-national coalitions/alliances). ${ }^{33}$ Yet on the other hand, convergence is also focused around the conduct of crisis-management operations that can vary in intensity across the conflict spectrum ('three block war') ${ }^{34}$ and is predicated upon the limitations of technology to control the process of 'escalation' 35 and transform the nature of conflict. Hence, where appropriate, elements of the RMA with the potential to supplement the capacity of the major European powers to conduct such operations, have been adopted, notably in areas such as Command and Control, along with the development of flexible and mobile medium weight infantry forces and reforms to command structures to permit enhanced jointness. ${ }^{36}$

In contrast to U.S. 'transformation', that has emphasized the acquisition of stand-

\footnotetext{
${ }^{30}$ Sperling, "Capabilities Traps and Gaps," 453-59; Soren Lungu, "The US Military-Technological Revolution and the 'Europeanization' of the French Industrial Sector During the 1990s," RUSI Journal 149, no.1 (spring, 2004): 58-63.

31 Reynolds, "Building the Future Force: Challenges to Getting Military Transformation Right," Contemporary Security Policy 27, no. 3 (winter 2006): 435-71.

${ }^{32}$ On EBO see Joshua Ho, "The Dimensions of Effects Based Operations," Defence Studies 5, no.2 (spring 2005): 169-87; on NEC and the Effects Based Approach to Operations see J.S. Meiter, "Network Enabled Capabilities: A Theory Desperately in Need of Doctrine," Defence Studies 6, no.2 (spring 2006): 189-214.

33 Although Germany lags behind Britain and France in the development of doctrine on EBAO and in investment in high-technology weapons systems in support of NEC (Sperling, 2004: 457; Lungu, 2004b).

${ }^{34}$ The former Commandant of the Marine Corps (1995-99), General Charles Krulack argued in favor of developing the ability to deal with 'three block warfare'. This encompassed the idea that U.S. forces would be most likely to encounter the rapid emergence of simultaneous humanitarian, peacekeeping/post-conflict reconstruction and high-intensity conventional warfighting operations in urban environments as small as 'three blocks', though his ideas were marginalized within the Marines until 2005. See Ho, "Dimensions of Effects Based Operations," 182-83; Steven Metz, "America's Defense Transformation: A Conceptual and Political History," Defence Studies 6, no.1 (spring 2006): 7; Terry Terriff, "Of Romans and Dragons: Preparing the U.S. Marine Corps for Counterinsurgency," Contemporary Security Policy 28, no.1 (spring 2007): 143-62.

${ }^{35}$ As John Stone pertinently notes, Carl von Clausewtiz posited that in seeking to compel an adversary to one's will through the destruction of his military, war would escalate to its 'pure' form: 'an explosion of uncontrolled violence'. However, Clausewitz identified two intervening factors, political and technical, that temper escalation. Technology can impede escalation by enabling the rapid and decisive defeat of the enemy, whilst the political context of a conflict can obstruct escalation, as the level of violence in war is directly proportional to the political aims on behalf of which a conflict is fought. See John Stone, "Politics, Technology and the Revolution in Military Affairs," Journal of Strategic Studies 27, no.3 (2004): 409-18.

${ }^{36}$ Supported by more a modest emulation of the U.S. infantry's 'Future Effects System' in Britain this has taken the form of the Future Rapid Effect System (FRES); in France, the Scorpion/Future Combat System. The German 'Infantryman of the Future System' is currently at an early stage of development.
} 
off capabilities and development of concepts and doctrine permitting Rapid and Decisive Operations against peer or near peer competitors ${ }^{37}$, the focus of West European reform has also been upon the ability to put 'boots on the ground', and on ensuring the development of skills necessary to conduct effective COIN, peacekeeping and postconflict reconstruction operations. Consequently, reforms have emphasized the effective integration of civilian and military contributions, not only to achieving strategic effects in high-intensity warfighting and RDO, but also in low-medium intensity peace-support and post-conflict reconstruction operations (termed the 'Comprehensive Approach' in the UK; the 'Synergy' of Effects in France). ${ }^{38}$ As Sperling highlights: 'French and British [military capability] concerns complement rather than compete with one another, despite their different levels of trust and preference for autonomy vis-à-vis the U.S. ${ }^{39}$

Whilst British and French 'third-order' reform processes followed a similar temporal sequence in respect to the order of reforms to the objectives and instruments of policy, the 'paradigm shift' in French institutional forums to embeddedness within ESDP took place in conjunction with changes to the objectives of French defense policy in February 1994, well before changes to the instruments of policy, in October 1996. Although it is only possible to identify incremental change to the settings of British policy on institutional venues (in the form of the gradual embedding of British defense policy within ESDP following the October 1998 Saint Malo agreement), this followed a very different sequence to France, as the Saint Malo Initiative (October 1998) took place three months after the Strategic Defence Review (SDR) ended. France and Britain display divergence in temporal location, taking place in 1997-98 (UK) ${ }^{40}$ and 1994-96 (France) and the reforms also differ in pace. The SDR was 14 months in duration, from May 1997 to July 1998. Reforms to French defense policy objectives began in February 1994 under Prime Minister Edouard Balladur, however, reform to the policy instrument was finalized in October 1996 - a period of 32 months.

Germany is a case of significant divergence in all three aspects of temporality: in temporal location - with a shift to crisis-management and 'full-spectrum' operations taking place in 2003 - and in sequencing, as reforms to the objectives of policy have only been accompanied by change to the 'settings' of policy instruments. On the dimension of pace, reform to the objectives of German policy took place over a comparatively rapid six month period - from May to October 2003. Finally, Germany has displayed strong

\footnotetext{
${ }^{37}$ See Metz, "America's Defense Transformation: A Conceptual and Political History". See also Kevin P. Reynolds, "Building the Future Force: Challenges to Getting Military Transformation Right," 435-71. It is important to note that the release of the US Army/Marines Country Insurgency Field Manual FM-24 (December 2006) represents a notable recognition of the limitations of technology to control the process of 'escalation' in the conduct of counterinsurgency operations and irregular warfare.

${ }^{38}$ These concepts are intended to facilitate the full integration of the diplomatic, military, economic and informational dimensions of military operations.

${ }^{39}$ Sperling, "Capabilities Traps and Gaps: Symptom or Cause of a Troubled Trans-Atlantic Relationship," 457. However, despite the development of a Joint Reaction Force in 2003, German reforms have proposed only successive alterations to the 'settings' of the policy instrument, due to the retention of conscription and the extent to which Germany lags behind Britain and France in its investment in high-technology weapons systems. Lungu, "Military Modernization and Political Choice: Germany and the US-Promoted Military Technological Revolution During the 1990s," 261-72.

${ }^{40}$ The 2002 'New Chapter' and 2004 Defence White Paper spelt out more clearly the implications of 'third order change' in terms of capabilities and military structures and also paved the way for new doctrinal development.
} 
continuity in respect to institutional forums, in the form of the persistence of the 'bridge role' and 'bi-furcated' Federal Executive.

At face value, Britain, France and Germany display strong divergence in relation to the institutional forums of defense policy. Britain, remains firmly committed to the trans-Atlantic relationship through NATO, despite the incremental Europeanization of its defense policy following the October 1998 St. Malo Accord; French defense policy prioritizes ESDP, although it is increasingly Atlanticised, symbolized by its immanent return to NATO's integrated military command structures; whilst Germany continues to promote a 'bridge role' between ESDP and NATO.

The longer-term development of the EU as an increasingly militarized regional and global actor, notably since the launch of EDSP at the Helsinki European Council of December 1999, would appear to indicate the development of a rival security organization to NATO with overlapping competencies. The EU is gradually developing the structures and capabilities (following the December 1999 Helsinki Headline Goals $^{41}$, HHG 2010, Battlegroup Initiative ${ }^{42}$, creation of the European Capabilities Action Plan (ECAP) in December 2001 and the establishment of the European Defence Agency (EDA) in June 2003), to permit the conduct of more robust missions at the higher end of the conflict spectrum. This appears to present a growing competitor to NATO's Response Force (NRF) ${ }^{43}$, that was initiated at the November 2002 Prague Summit. At the same time, NATO is at the inception of developing its peace-support capabilities as outlined by the Comprehensive Political Guidance $(\mathrm{CPG})^{44}$, endorsed at the Riga Summit, November 2006.

European armed forces are therefore subject to a 'three-way capability stretch'. 45 Within the context of shrinking defense budgets, Britain France and Germany face commitments deriving from their own national defense requirements and the Headline Goal 2010/EDA procurement initiatives requiring the development of capabilities which will ensure an autonomous capacity for European military action. They also face the challenge of meeting the NATO's 2002 Prague Capabilities Commitment and initiatives developed under the Allied Command for Transformation, designed to enhance interoperability with U.S. forces and facilitate NRF deployments.

\footnotetext{
${ }^{41}$ The HHG established a Rapid Reaction Force (RRF) consisting of 60,000 troops deployable at 60 days notice, sustainable for up to one year in the field, capable of fulfilling not only the low-end Petersburg Tasks, but also of sustaining one medium- to high-intensity operation.

${ }^{42}$ The Battlegroup Initiative approved at the May 2004 European Council created up to 15 Battlegroups, each consisting of 1,500 troops, deployable within 15 days, enhancing the EU's capacity to launch simultaneous low-high-intensity rapid response operations, attaining full operational capability in 2007.

${ }^{43}$ A high-readiness, technically advanced, joint air, naval and infantry force of 21,000 troops (of which only 300 are American) able to remain in the field for up to 3 months, deployable within 5 and 30 days, attaining operational readiness in October 2004.

${ }^{44}$ CPG builds upon the 1999 Strategic Concept by identifying the core threats to NATO as international terrorism, the proliferation of Weapons of Mass Destruction, failed or failing states, regional crises, misuse of technologies and disruption of resource flows. CPG outlined the necessity of being capable of conducting operations which require the comprehensive coordination of 'several authorities, institutions and nations' in the context of operations that may involve the simultaneous conduct of combat, stabilization, reconstruction, reconciliation and humanitarian missions (termed the 'Comprehensive Approach'). CPG, 29 November, 2006, pt. 16, h-i.

${ }^{45}$ Sperling, "Capabilities Traps and Gaps: Symptom or Cause of a Troubled Trans-Atlantic Relationship," 457.
} 
However, such a pessimistic picture of disjuncture between the EU and NATO is unfounded. Instead, it is perhaps more accurate to point to an increasing degree of complementarity and co-operation in terms of military capacity, command facilities and force planning ${ }^{46}$ and a growing strategic coherence between NATO and the EU. This complementarity is evidenced by the March 172003 Berlin-Plus Agreement. Berlin Plus provides the EU with access to NATO operational planning, capabilities and assets for EU crisis management operations and places the NATO's Supreme Allied Commander in Europe (DSACEUR) in command of the EU operation (under the authority and guidance of the EU's PSC).

Berlin Plus also put in place arrangements for mutually reinforcing capability requirements. ${ }^{47}$ The establishment of the EU-NATO Capability Group in May 2003 has sought to foster complementarity in procurement initiatives between the two organizations. This is a process that has been facilitated by attempting to ensure that the same country takes the lead role in developing the matching capabilities within each of the institutions (for example Germany's role as the lead nation in the development of strategic airlift capabilities within NATO and ESDP). The work of the EU-NATO Capability Group is supplemented by regular meetings between EU and NATO officials. $^{48}$ Moreover, on 3 October 2005 a permanent NATO liaison within the EU Military Staff and a permanent EU planning cell at SHAPE were established. ${ }^{49}$

Despite the EU's gradual shift towards the capacity to undertake higher-intensity tasks, the NRF - heavier, designed for major theater operations and linked to U.S. policy - remains strongly differentiated from the RRF, that is lighter and focused on low-medium intensity crisis-management mechanisms and less rapidly deployable. ${ }^{50}$ This is reflected in the nature of ESDP missions which have largely been at the lower end of the conflict spectrum (rule of law, policing/police advisory missions, security sector reform and border assistance missions), operational experience that is reinforcing

\footnotetext{
46 Thomas S. Mowle and David H. Sacko "Global NATO: Bandwagoning in a Unipolar World," Contemporary Security Policy 28, no. 3 (winter, 2007); Sten Rynning, NATO Renewed: The Power and Purpose of Trans-Atlantic Cooperation (Houndmills: Palgrave Macmillan, 2005), 155; 172; Stale Ulriksen "Requirements for Future European Military Strategies and Force Structures," International Peacekeeping 11, no.3 (2004): 468. Whilst the EDA's 'Initial Long-Term Vision for European Capability and Capacity Needs' notes the necessity for a 'more characteristically European approach' to NEC 'different in ambition and character (for example with a strong emphasis on civil-military interoperability, and on the tactical level)' it notes that efforts must 'ensure interoperability with the leading efforts of the U.S. in this area' and 'nested within NATO conceptual frameworks and standards'. Initial Long-Term Vision for European Capability and Capacity Needs (Brussels: European Defence Agency, October 2006), 20-21.

47 Paul Cornish and Geoffrey Edwards, "The Strategic Culture of the EU: A Progress Report," International Affairs 81, 4 (autumn 2005): 814-8; Jolyon Howorth, Security and Defence Policy in the European Union (Houndmills: Palgrave Macmillan, 2007: 170; Rynning, NATO Renewed: The Power and Purpose of Trans-Atlantic Cooperation, 175; Richard Whitman, "NATO, the EU and ESDP: An Emerging Division of Labour?" Contemporary Security Policy 25, no.3 (2004): 430.

48 These include at a minimum of two meetings at the level of Foreign Ministers; three meetings at Ambassadorial level per semester; two meetings at the level of Military Committee per semester and regular and routine meetings at the committee and staff level.

${ }^{49}$ Cornish and Edwards, "The Strategic Culture of the EU: A Progress Report," 812.

${ }^{50}$ Howorth, Security and Defence Policy in the European Union, 14-15; Rynning, NATO Renewed: The Power and Purpose of Trans-Atlantic Cooperation, 157.
} 
the EU's expertise and credibility in civilian crisis-management and prevention. ${ }^{51}$ Of the 20 missions so far conducted under ESDP, only four Operations (EU-FOR Althea, EU-FOR Tchad/RCA, EU-FOR Concordia and EU-FOR RD Congo) have involved the deployment of peace-support forces capable of conflict at the higher-intensity of the conflict spectrum. In contrast, three of NATO's five current military operations (ISAF, KFOR and Operation Active Endeavour) involve the deployment of troops prepared for conflict at higher end of the conflict spectrum. ${ }^{52}$ Given the additional difficulties associated with the brokering of agreement on NATO's 'Comprehensive Approach', ESDP is likely to remain the institutional forum of choice for the conduct of lower intensity crisis-management/prevention operations.

Additionally, NATO and the EU are emerging as organizations with more distinct regional responsibilities. The 12 December 2003 European Security Strategy (ESS) heralds the EU's responsibility to contribute to global security by tackling the key threats of terrorism, the proliferation of WMD, regional conflicts, state failure and organized crime. ${ }^{53}$ However, although the strategic radius of EU operations has expanded significantly since $1999^{54}$, ESDP missions are predominantly focused on the geo-strategic neighborhood of the EU: the Western Balkans, Middle East, Sub-Saharan Africa and Caucuses. Whilst CPG outlines a set of similar challenges for NATO ${ }^{55}$ the military deployments of the Atlantic Alliance have taken on a global character since September $11^{\text {th }}$, as illustrated by its most prominent contemporary operation, ISAF in Central Asia. Hence although both the NRF and RRF initiatives draw specifically upon the troops of the British Joint Response Force, French EMF and German 'rapid reaction force', the relationship between ESDP and NATO cannot be thought of in zero-sum terms. ESDP is not indicative of a fissure in the Atlantic Alliance and the gradual emergence of a European rival to NATO ${ }^{56}$ Posen succinctly captures this combination of partly overlapping and partly complementary competencies of the two institutional forums: 'European members of NATO have not abandoned that Alliance; instead they

\footnotetext{
51 The civilian dimension of ESDP, launched at the June 2000 European Council, has been bolstered by the Civilian Headline Goal 2008 and 2010.

52 NATO support for the AU Peacekeeping Mission in Darfur (AMIS) involves the provision of air transport for peacekeepers and training for AU officers; the NATO Training Assistance Implementation Mission in Iraq is focused on training Iraqi Security Forces.

53 'A Secure Europe in a Better World: European Security Strategy, 12 December 2003, pp.1-5.

${ }^{54}$ Whilst the EU's 'strategic radius' does not yet match that of NATO, it has expanded significantly since the end of the Cold War. Jones (2007: 216) calculates this 'strategic radius' as extending 4,000km from Brussels. Headline Goal 2010 agreed a distance of 6,000km from Brussels as a planning basis for military operations (German Defence White Paper, 2006, p. 38.

55 'The principle threats to the Alliance are international terrorism and the proliferation of weapons of mass destruction and their delivery systems, as well as instability caused by failed or failing states; regional crises; misuse of new technologies; and the disruption of the flow of vital resources.' The Riga Summit: A Reader's Guide, $6^{\text {th }}$ July, 2007, p.4.

${ }^{56}$ David H. Dunn, "European Security and Defence Policy in the American Security Policy Debate: Counterbalancing America or Rebalancing NATO?" Defence Studies 1, no.1 (spring, 2001): 153; Howorth, Security and Defence Policy in the European Union, 44-45; Ulriksen, "Requirements for Future European Military Strategies and Force Structures," 469-71. See also UK Defence White Paper 2004, pt. 2.19: 'The UK is a strong supporter of developing EU military capability to complement NATO, rather than competing with it.' The 2006 German Defence White Paper, p. 40 states: 'The EU and NATO are not in competition with one another, but make complementary contributions to our security.'
} 
have supported the construction of a parallel structure and indeed regularly support improved cooperation between NATO and ESDP'. ${ }^{7}$

\section{Table 1: Patterns of Convergence and Divergence in Post-Cold War British, French and German Military Reform}

\begin{tabular}{|c|c|c|c|c|}
\hline & Objectives & Instruments & Institutional Fora & Temporality \\
\hline Britain & $\begin{array}{l}\text { From Cold War role } \\
\text { of territorial and } \\
\text { alliance defense to } \\
\text { global low-high } \\
\text { intensity expeditionary } \\
\text { crisis-management } \\
\text { operations, as part of } \\
\text { multi-national } \\
\text { coalitions. }\end{array}$ & $\begin{array}{l}\text { Professional Force (from } \\
\text { 1962). } \\
\text { Reduction from Cold War } \\
\text { Force of } 306,000 \text { (1990) } \\
\text { to 226,000 troops. } \\
\text { Creation of 'Joint } \\
\text { Reaction Force' and more } \\
\text { flexible planning and } \\
\text { command capabilities in } \\
\text { 1996/97. Capability } \\
\text { procurement increasingly } \\
\text { focused on requirements } \\
\text { of asymmetric and net- } \\
\text { centric warfare. }\end{array}$ & $\begin{array}{l}\text { Continuity in } \\
\text { prioritization of } \\
\text { NATO; though } \\
\text { incremental shift } \\
\text { towards embedding } \\
\text { within ESDP } \\
\text { following Anglo- } \\
\text { French October } 1998 \\
\text { Saint Malo Accord. }\end{array}$ & $\begin{array}{l}\text { Temporal Location: May } \\
\text { 1997-July 1998, } \\
\text { incremental shift towards } \\
\text { embedding within ESDP in } \\
\text { October } 1998 . \\
\text { Pace: } 14 \text { months. } \\
\text { Sequencing: Objectives, } \\
\text { Instruments, } \\
\text { Institutional Forums. }\end{array}$ \\
\hline France & $\begin{array}{l}\text { From Cold War role } \\
\text { of territorial defense to } \\
\text { global low-high } \\
\text { intensity expeditionary } \\
\text { crisis-management } \\
\text { operations, as part of } \\
\text { multi-national } \\
\text { coalitions. }\end{array}$ & $\begin{array}{l}\text { Conscript Force } \\
\text { (1905-1996); } \\
\text { Professional Force (from } \\
\text { 1996). Reduction from } \\
\text { Cold War force of } \\
400,000 \text { to } 250,000 \text { troops } \\
\text { in } 1996 . \\
\text { Creation of 'Joint } \\
\text { Reaction Force' and more } \\
\text { flexible planning and } \\
\text { command capabilities in } \\
\text { 1996. Emphasis upon } \\
\text { development of } \\
\text { autonomous technology } \\
\text { for ESDP (Galileo, FFI) }\end{array}$ & $\begin{array}{l}\text { From 'semi-detached' } \\
\text { defense policy during } \\
\text { Cold War, between } \\
\text { NATO and national } \\
\text { strategic autonomy to } \\
\text { post-Cold War } \\
\text { prioritization of } \\
\text { ESDP, and } \\
\text { increasingly active } \\
\text { role in strengthening } \\
\text { NATO. }\end{array}$ & $\begin{array}{l}\text { Temporal Location: } \\
\text { February } 1994 \text { - October } \\
1996 . \\
\text { Pace: } 32 \text { months. } \\
\text { Sequencing: Institutional } \\
\text { Forums, Objectives, } \\
\text { Instruments. }\end{array}$ \\
\hline Germany & $\begin{array}{l}\text { From Cold War role } \\
\text { of territorial and } \\
\text { alliance defense to } \\
\text { global low-high } \\
\text { intensity expeditionary } \\
\text { crisis-management } \\
\text { operations, as part of } \\
\text { multi-national } \\
\text { coalitions. }\end{array}$ & $\begin{array}{l}\text { Conscript Force (from } \\
\text { 1956). Reduction from } \\
370,000 \text { troops with } \\
170,000 \text { conscripts (set by } \\
\text { the } 1990 \text { Two Plus Four } \\
\text { Treaty), to } 252,500 \text { troops } \\
\text { with 50,000 conscripts by } \\
2003 \text {. } \\
\text { 'Creation of Joint } \\
\text { Reaction Force' and more } \\
\text { flexible planning and } \\
\text { command capabilities in } \\
\text { 2003. Lower investment } \\
\text { in high-technology } \\
\text { weapons systems. }\end{array}$ & $\begin{array}{l}\text { Continuity in 'bridge } \\
\text { role' between ESDP/ } \\
\text { NATO and in } \\
\text { 'bifurcated' Federal } \\
\text { Executive in form of } \\
\text { 'Europeanized' } \\
\text { Foreign Ministry and } \\
\text { 'Atlanticized' Defense } \\
\text { Ministry. }\end{array}$ & $\begin{array}{l}\text { Temporal Location: May } \\
2003 \text { - October } 2003 \\
\text { (reform of objectives). } \\
\text { Pace: } 6 \text { months (reform of } \\
\text { objectives). } \\
\text { Sequencing: Objectives } \\
\text { (changes only to the } \\
\text { 'settings' of instruments and } \\
\text { continuity in institutional } \\
\text { forums). }\end{array}$ \\
\hline
\end{tabular}

\footnotetext{
${ }^{57}$ Posen, "The European Security and Defence Policy: Response to Unipolarity," 184.
} 


\section{Competing Theoretical Frameworks: Realist and Cultural Approaches}

\section{Realism and Military Reform}

Neo-realist accounts of military reform suggest that the anarchic logic of the international system drives change at the domestic level, leading to the adoption of new military methods. ${ }^{58}$ The changing systemic distribution of capabilities and new security challenges, coupled with the necessity of survival in a 'self-help' world leads to two possible outcomes. Firstly, emulation, the adoption of 'best practice' in order to enhance competitive effectiveness: 'Contending states imitate the military innovations contrived by the country of greatest capability and ingenuity...competition produces a tendency towards sameness of the competitors... and so weapons of major contenders and even their strategies begin to look much the same'. ${ }^{59}$ Secondly, innovation, the discovery of new knowledge, invention of new practices or their recombination in new forms. ${ }^{60}$

Neo-realism posits that executive decision-makers enjoy a high-level of autonomy in translating threats from the international security environment into change to military doctrine and structure and in overcoming domestic opposition and bureaucratic politics, due to the intensity of external threat. ${ }^{61}$ Convergence of the objectives and instruments amongst states of broadly similar relative material power and geographical location (and therefore a similar level of external vulnerability) is an inevitable consequence of the seismic shifts in the distribution of international power brought about by the end of the Cold War. ${ }^{62}$ Neo-realism points to two main factors, common to Britain, France and Germany that have determined a pattern of 'clustered convergence' in Europe characterized by only a partial emulation of the U.S.-led model of high-intensity force projection and RMA: the complexity of the post-Cold War security environment and resource constraints which increase the risks consequent upon emulation, creating an incentive to bandwagon of U.S. power. ${ }^{63}$

Firstly, in the relative absence of great power war and the diverse nature of conflict and threats in the post-Cold War international system, it has been difficult for European states to define 'best practice'. On the one hand, the US-led 1991 Gulf War, 1999 Kosovo Conflict, 2001 attack on Afghanistan and 2003 attack on Iraq, highlighted the utility of technological prowess in the context of expeditionary high-intensity warfighting, demonstrating the success of the RMA. ${ }^{64}$ Yet, at the same time, the Iraq conflict

\footnotetext{
58 Posen, The Sources of Military Doctrine: France, Britain and Germany Between the Wars; ResendeSantos, Neorealism, States and the Modern Mass Army.

${ }^{59}$ Waltz, Theory of International Politics, 127.

${ }^{60}$ Resende-Santos, Neorealism, States and the Modern Mass Army, 72.

${ }^{61}$ Posen, The Sources of Military Doctrine: France, Britain and Germany Between the Wars, 77; Rynning, "Shaping Military Doctrine in France: Decision Makers Between International Power and Domestic Interests," 85.

${ }^{62}$ Jones, The Rise of European Security Cooperation, 243; Posen, "The European Security and Defence Policy: Response to Unipolarity," 149-86.

${ }^{63}$ On 'clustered convergence' see Resende-Santos, Neorealism, States and the Modern Mass Army 2007: 78.

${ }^{64}$ Boot, "The New American Way of War," 41-58; Lungu, "Military Modernization and Political Choice: Germany and the US-Promoted Military Technological Revolution During the 1990s," 265; Andrew L. Stigler, "A Clear Victory for Air Power: NATO’s Empty Threat to Invade Kosovo," International Security,
} 
post-2003, the NATO ISAF mission and U.S./European involvement in the former Yugoslavia and Africa during the 1990s, have demonstrated the dangers inherent in a reliance on air power, stand-off precision-strike weapons systems and command, control and communications systems, in the context of peacekeeping, post-conflict reconstruction and policing tasks and counter-insurgency operations. ${ }^{65}$ Secondly, the nature of Britain, France and Germany as 'second-rank' powers, constraining their resource-technological capacity to copy the RMA, magnifying the risks associated with emulation. ${ }^{66}$ Hence, emulation of the RMA and U.S. 'best practice' is most evident in areas of least risk and cost - the reorganization of military structures in the form of the creation of Joint Reaction Forces and the development of technologies essential to ensure continued interoperability with the U.S., as well as an autonomous European capacity for military action. $^{67}$

Neo-realist thought suggests two main readings of the development of ESDP and patterns of overlap/complementarity in institutional forums. The first view is that Europe is engaging in a form of 'soft' balancing against the U.S., using non-military tools to frustrate unilateral action, forming the first stage of attempts by European states to contain a potential opponent. ${ }^{68}$ The other suggests that ESDP is not a potential rival to NATO and the U.S., but instead forms the development of 'reformed bandwagoning' within the alliance following the failure of Europe's pursuit of a 'binding ${ }^{69}$ strategy

27 , no.3 (winter 2002/03): 124-57. It is however important to note that, the utility of air power in force-onforce combat is contested. In spite of the success of the U.S. in targeting Serbian infrastructure and economy, the contested authority of U.S. air power was demonstrated by the Kosovo conflict of 1999, that illustrated how: 'a well-operated if obsolescent integrated air defense system can defend a ground force skilled at camouflage and deception,'; Posen, "Command of the Commons: The Military Foundations of U.S. Primacy," 28. See also Galia Press-Barnathan "The Myth of Airpower in the Persian Gulf and the Future of Warfare," International Security 26, no.2 (summer 2001): 5-44; Stephen Walt, "Taming American Power," Foreign Affairs 84, no.5 (autumn 2005): 116; R. Williams, "Is the West's Reliance on Technology a Panacea for Future Conflict or Its Achilles Heel?" Defence Studies 1, no.2 (2001): 48.

65 "Brains, Not Bullets," The Economist, October 25 2007. David Betz, "Redesigning Land Forces for Wars Amongst the People," Contemporary Security Policy 28, no.2 (summer 2007): 221-243; Stephen Biddle, "Allies, Airpower and Modern Warfare: The Afghan Model in Afghanistan and Iraq," International Security 30, no. 3 (winter 2005/06): 161-76; Daniel L. Byman, "Building the New Iraq: The Role of Intervening Forces," Survival 45, no.2 (summer 2003): 57-71; Carter Malkasian, "Did the United States Need More Forces in Iraq? Evidence from Al-Anbar," Defence Studies 8, no.1 (spring 2008): 78-104; Michael E. O'Hanlon, "A Flawed Masterpiece," Foreign Affairs 81, no.3 (summer 2002); Thomas E. Ricks, Fiasco: The American Military Adventure in Iraq (New York: Penguin, 2006).

${ }^{66}$ Resende-Santos, Neorealism, States and the Modern Mass Army, 73.

${ }^{67}$ Forster, Armed Forces and Society in Europe, 46; Holger Mey, "The Revolution in Military Affairs: A German Perspective," Comparative Strategy 17, no.3 (summer 1998): 316; Sperling, "Capabilities Traps and Gaps: Symptom or Cause of a Troubled Trans-Atlantic Relationship?" 456-59.

${ }^{68}$ On 'soft balancing' see Robert A. Pape, "Soft Balancing Against the United States," International Security 30, no.1 (summer 2005): 7-45; Thazha Varkey Paul, "Soft Balancing in the Age of U.S. Primacy," International Security 30, no.1 (summer 2005): 46-71; Barry R. Posen, "ESDP and the Structure of World Power," International Spectator 34, no.1 (spring 2004): 5-17; Posen, "The European Security and Defence Policy: Response to Unipolarity," 149-86 and Stephen Walt, Taming American Power: The Global Response to U.S. Primacy (New York: Norton, 2005), 129.

69 'Binding' refers to the ability of smaller alliance partners to use institutional ties to restrain a larger alliance partner from pursuing unilateral policies and avoid 'entrapment' by a more powerful ally. See Randall L. Schweller, Deadly Imbalances: Tripolarity and Hitler's Strategy of World Conquest (New York: Columbia University Press, 1998), 70-72. 
through NATO. ${ }^{70}$ The fear of 'entrapment' into U.S. policy, or 'abandonment" ${ }^{71}$ through the withdrawal of the US security guarantee has incentivized policy leadership in Britain, France and Germany on behalf of the pooling of military resources with European Allies. This has taken place through the 'Europeanization' of NATO and development of the NRF (granting increased influence in Washington and a global high-intensity capability in major theater war) and through the simultaneous development of an increasingly militarized ESDP (small, self-contained Battlegroups permitting autonomous action by the EU within its geopolitical neighborhood, in cases of US disinterest). ${ }^{72}$

ESDP forms an attempt by European states to maintain and manage the Atlantic Alliance within the context of complex post-Cold War security threats and strategic interests which have a largely unifying, but sometimes differentiated impact on Europe and the U.S.. Whilst bandwagoning runs the risk that the U.S. may pose a threat to its great power allies once it has eliminated other opponents, bandwagoning emerges as the most rational strategy open to European states. ${ }^{73}$ It is the strategy of least risk and cost; a means with which to attempt to gain some, albeit limited, influence over U.S. policy and 'share in the spoils of victory' against common opponents. ${ }^{74}$ This convergence in institutional forums is consistent with the convergence of capabilities: 'Europe's attention is directed towards enhancing European autonomy on security affairs while redressing the acknowledged capabilities shortfalls to meet the needs of the [Atlantic] alliance'. ${ }^{75}$

Yet despite longer-term convergence trends in objectives, instruments and institutional forums, Britain, French and German reforms display significant differentiation in temporality. It is here that neo-realism's explanatory capacity is found wanting, for it fails to fully account for the role of domestic power relationships in determining the pace, sequencing and temporal location of military reform due to the emphasis it places upon the preoccupation of civilian leaders with the 'national interest' rather than domestic political interests. Neoclassical realism provides a mechanism with which to account for the intervening role played by unit-level variables. The theory

\footnotetext{
${ }^{70}$ On reformed bandwagoning see Press-Barnathan, "Managing the Hegemon: NATO Under Unipolarity," 271-309; Stephen G. Brooks and William C. Wohlforth, "Hard Times for Soft Balancing: International Security, 30, no.1 (2005): 80; 91-92; Keir A. Lieber and Gerard Alexander, "Waiting for Balancing: Why the World Is Not Pushing Back," International Security 30, no.1 (2005): 109-39.

${ }^{71}$ Press-Barnathan, "Managing the Hegemon: NATO Under Unipolarity," 307-08.

${ }^{72}$ Jones, The Rise of European Security Cooperation 2007: 219; King, "Towards A Transnational Europe: The Case of the Armed Forces," 331; Posen, "The European Security and Defence Policy: Response to Unipolarity," 180; Rynning, NATO Renewed: The Power and Purpose of Trans-Atlantic Cooperation, 151; 157.

${ }^{73}$ Hyde-Price, European Security in the $21^{\text {st }}$ Century: The Challenge of Multipolarity, 50.

74 "[States] may not feel immediately threatened by the power which provides them the spoils or feel that the potential threat is more distant. In the context of an existing conflict, therefore, watching a friend gain power may not be completely comforting, but the short-term priorities of security demand that you gain now against your enemy and worry about the postwar balance of power with your friend later". Eric J. Labs, "Beyond Victory: Offensive Realism and the Expansion of War Aims," Security Studies 6, no.4 (winter 1997): 15-16. As Lieber and Alexander highlight: 'The U.S. is plausibly threatening to only a limited number of states and terrorist groups. Most other major powers share the U.S. interest in countering these regimes and groups...other major powers lack an underlying motivation to compete strategically with the United States." Robert J. Art et al, "Striking the Balance," International Security 30, no.3 (winter 2005/06): 192.

${ }^{75}$ Sperling, "Capabilities Traps and Gaps: Symptom or Cause of a Troubled Trans-Atlantic Relationship?" 458 .
} 
argues that whilst over the long-run states will seek to maximize their international influence according to their relative material power resources, 'state power' - the impact of the strength of a country's state apparatus and its relations to the surrounding society upon ability of the state to mobilize and extract resources from society - forms the central intervening unit-level variable explaining short-medium term temporal divergence. ${ }^{76}$

In his neoclassical realist account of French military reform, Rynning argues that although the international distribution of capabilities - relative material power - is the key driver of convergence, 'strategic leadership' by statesmen emerges as the crucial determinant of 'state power'. ${ }^{77}$ Rynning identifies three facets of strategic leadership: strategic innovation - the role of statesmen in linking strategic agendas to doctrinal and structural change; institutional protection - the ability of political leaders to anchor new ideas within political institutions, manage institutional venues and disadvantage alternative ideas or proponents of the status quo; finally, 'allied cooperation' - the framing of reform with common 'strategic readings' of a state's international partners. ${ }^{78}$ Convergence and divergence can therefore be explained by a focus upon the strength of the international power shift and the extent to which policy leaders are able to successfully manage these three aspects of policy change: 'Shifts in national power provoke policy change...only after central decision-makers have structured the reform process and articulated a new doctrinal blueprint capable of winning significant domestic support'. ${ }^{79}$

However, it is important to note that the implications of shifts in national power are not always immediately clear, impacting upon the temporality of military reform over the short-term. Following significant systemic power shifts, a short term temporal lag with systemic imperatives is likely as states become more familiar with the radical changes in their strategic environment. This creates particular informational uncertainty and flux, requiring the readjustment and fine-tuning of strategy to the new configuration of constraints and opportunities. The temporal lag also reflects the potential costs of 'system punishment' that can stem from strategic miscalculation, hence states will tend to err on the side of caution and only make decisions based upon information that is as complete as possible, within the inherent constraint of systemic uncertainty.

In addition, whilst Rynning emphasizes the intervening role played by policy leadership in managing doctrinal change ${ }^{80}$, neoclassical realism also draws our attention to the central role played by domestic power relationships - the level of 'executive autonomy' in defense and security policy - in determining temporal divergence. ${ }^{81}$ As Rose states: 'Power analysis must also examine the strength and structure of states

\footnotetext{
${ }^{76}$ On 'state power' see Rose, "Neoclassical Realism and Theories of Foreign Policy," 152 and Taliaferro, "State Building For Future Wars: Neoclassical Realism and the Resource Extractive State," 479-80.

${ }^{77}$ Rynning, "Shaping Military Doctrine in France: Decisionmakers Between International Power and Domestic Interests," 90.

${ }^{78}$ Rynning, "Shaping Military Doctrine in France: Decisionmakers Between International Power and Domestic Interests," 90-92.

${ }^{79}$ Rynning, "Shaping Military Doctrine in France: Decisionmakers Between International Power and Domestic Interests," 104-16.

${ }^{80}$ Rynning, "Shaping Military Doctrine in France: Decisionmakers Between International Power and Domestic Interests," 114.

${ }^{81}$ Taliaferro, "State Building For Future Wars: Neoclassical Realism and the Resource Extractive State," 487-90.
} 
relative to their societies, because these affect the proportion of national resources that can be allocated to foreign policy'. ${ }^{82}$ In short, although policy leadership is an important variable, it is not a sufficient account of temporal divergence. The institutional structure of the state (the degree of centralization), the formal constitutional powers of the core executive (Presidents/Prime Ministers/Defense Ministers) over defense policy and nested and interlinked policy subsystems (defense/budgetary/social policy) form the framework for 'balancing domestic power'. ${ }^{83}$ Domestic power structures act to condition the ability and willingness of policy leaders to provide 'strategic leadership' on behalf of convergence with systemic power shifts.

The temporal location, sequencing and pace of British, French and German reform is dependent upon the strength of the international power shift, coupled with the autonomy afforded to the political executive in defense policy by domestic material power relationships. This determines whether policy leaders, over the short-medium term, will undertake 'strategic innovation' or promote 'strategic stasis' and whether 'institutional protection' will be given to new ideas or to Cold War policies on the objectives and instruments of defense policy. Executive autonomy is also the key intervening variable in explaining the extent to which policy leaders will be preoccupied with the domestic political ramifications of the 'framing' of military reform within NATO/EU 'allied cooperation' or with the 'national interest' and systemic imperatives. Within a context of low executive autonomy, 'culture' emerges as a resource employed by policy leaders in the 'balancing of domestic power' and the temporal management of reform.

\section{Culture and Military Reform}

The cultural turn in strategic studies argues that realist approaches cannot provide a full explanation of the scope and temporality of military reform because they treat the preferences of actors as given; national preferences and international reality are instead socially constructed. ${ }^{84}$ Norms emerge as a cause of action and constitutive, expressing actor identities, shaping how actors define their interests and providing standards of appropriate behavior. ${ }^{85}$ Culturalists regard military policy as driven by ideas rather than material factors, representing a 'culturally bounded, institutionally-embedded pattern persisting over time' and a national security culture that: 'predispose(s) societies in general and political elites...toward certain actions and policies'. ${ }^{86}$ As Fischer states: 'It

\footnotetext{
${ }^{82}$ Rose, "Neoclassical Realism and Theories of Foreign Policy," 174.

${ }^{83}$ Rynning, "Shaping Military Doctrine in France: Decisionmakers Between International Power and Domestic Interests," 116.

${ }^{84}$ See Peter J. Katzenstein ed., The Culture of National Security: Norms and Identity in World Politics (New York: Columbia University Press, 1996); Kerry Longhurst, "Why Aren't The Germans Debating the Draft? Path Dependency and the Persistence of Conscription," German Politics 12, no.2 (summer 2003)147-65; Longhurst, Germany and the Use of Force: The Evolution of German Security Policy; Alexander Wendt, "Anarchy is What States Make of It: The Social Construction of Power Politics," International Organization 46, no.2 (1992): 319-425.

${ }^{85}$ Theo Farrell, "Culture and Military Power," Review of International Studies 24, no.3 (autumn 1998): 407-18; Colin Gray, "Strategic Culture as Context: The First Generation of Theory Strikes Back," Review of International Studies, 25, no. 1 (spring, 1999): 49-69.

${ }^{86}$ Berger, Cultures of Anti-Militarism: National Security Cultures in Germany and Japan; Duffield, World Power Forsaken: Political Culture, International Institutions and German Security Policy, 27.
} 
is not that institutions cause political action; rather it is their discursive practices that shape the behavior of actors who do, ${ }^{87}$

Hence the objectives of British, French and German defense policy are not conditioned by the imperative of self-help in an anarchic international system, but are instead subjective and consequent upon their distinct 'cultures of national security'. ${ }^{88}$ The persistence of territorial defense as the core objective of German defense policy until 2003 stems from the 'culture of anti-militarism' that is deeply rooted in the German political-military elite and society. This continues to predispose Germany to focus on low-medium intensity crisis-management operations. ${ }^{89}$ Similarly, the more active postCold War roles of Britain and France lie in the long-established traditions of low-high intensity expeditionary power projection that characterized their defense policies during the colonial era. ${ }^{90}$

Longhurst and Irondelle emphasize the role of 'path dependency' in social causation. ${ }^{91}$ This mirrors the insights of historical institutionalism that argues that institutions push historical development along particular paths, hence the effects of systemic forces are mediated by inheritance from the past. ${ }^{92}$ Institutions embody tool-kits of action that provide actors with ways of defining problems and 'logics of appropriate behavior' in a given situation - determining the persistence of conscription in France until 1997 and in Germany until the present day. As Irondelle states: 'On the question of conscription vs. professional armed forces the [French] army found itself faced with a question not just of practicability, but of identity'. ${ }^{93}$

In her work on British and French military doctrine Kier argues that in order to understand changes in military policy we must not only play close attention to the 'organizational culture' of the military, but also to the changing domestic political

\footnotetext{
${ }^{87}$ Frank Fischer, Reframing Public Policy: Discursive Politics and Deliberative Practices (Oxford: Oxford University Press, 2003), 28.

${ }^{88}$ The concept of strategic culture was initially associated with nuclear strategy, Jack, L. Snyder, The Soviet Strategic Culture: Implications for Limited Nuclear Options (Santa Monica, CA: RAND, 1977); Colin Gray, "National Styles in Strategy: The American Example," International Security 6, no.2 (1981): 21-47. Alistair Johnson cast the scope of strategic culture more broadly, relating it to a state's grand strategy: "an integrated system of symbols (e.g. argumentation structures, languages, analogies, metaphors) which act to establish persuasive and long-lasting strategic preferences by formulating concepts of the role and efficacy of military force in interstate political affairs and by clothing these conceptions in such an aura of factuality that the strategic preferences seem uniquely realistic and efficacious." Alistair I. Johnson, "Thinking About Strategic Culture," International Security 19, no.4 (1995): 46.

${ }^{89}$ Dalgaard-Nielsen, Germany Pacifism and Peace Enforcement; Longhurst, Germany and the Use of Force: The Evolution of German Security Policy: 1990-2003.

${ }^{90}$ Alistair Miskimmon, "Continuity in the Face of Upheaval: British Strategic Culture and the Blair Government," European Security 13, no.3 (2004): 87-113; Rod Thornton, "A Welcome Revolution? The British Army and the Changes of the Strategic Defence Review," Defence Studies 3, no.3 (2003): 38-62; Mark Smith, "Britain: Balancing Instinctive Atlanticism," Contemporary Security Policy 26, no.3 (2005: 447-469.

${ }^{91}$ Longhurst, "Why Aren't the Germans Debating the Draft? Path Dependency and the Persistence of Conscription; Bastien Irondelle, "Civil-Military Relations and the End of Conscription in France," Security Studies 12, no.3 (2003): 157-87.

${ }_{92}$ Peter A. Hall and Rosemary C.R. Taylor, "Political Science and the Three New Institutionalisms," Political Studies 44, no.5 (winter 1996): 936-57.

${ }^{93}$ Irondelle, "Civil-Military Relations and the End of Conscription in France,"176.
} 
context and civil-military relations. ${ }^{94}$ For Kier, culture forms an intervening variable: 'Domestic politics set constraints; the military's culture interprets these constraints; the organizational culture is the intervening variable between civilian decisions and military doctrine'. 95

\section{Explaining Policy Change: Critical Junctures, Policy Learning and Normative Entrepreneurship}

Culturalist accounts have drawn criticism for their inability to explain change, as they posit that policy displays a high level of inertia due to deeply-embedded nature of 'core' or 'central' beliefs. ${ }^{96}$ Change is gradual, with radical change only possible in the context of 'external perturbations' or 'critical junctures' - seismic and formative historical events that illustrate the failure of existing objectives and instruments of defense policy and empower new actors and policy ideas within institutions. ${ }^{97}$

Public policy theories elaborate on the structure/agency dynamic at the heart of policy change - notably the 'advocacy coalition framework (ACF)' and 'multiple streams framework'. ${ }^{98}$ Irondelle posits a synthesis of these two approaches in explaining the professionalization of the French armed forces in the context of 'path dependency'. 99 Whilst exogenous shock is critical, the policy entrepreneur is decisive in spurring 'critical conjuctures' - coupling the three streams of the policy process - problems, policies and politics. $^{100}$

However, the presence of competing advocacy coalitions is also important. ${ }^{101}$ The ACF conceptualizes policy as the result of competition between coalitions structured by policy beliefs and values. Change is not only the result of competition amongst interests, but also learning, within and between coalitions. Initiating or hindering policy-learning processes are vital tools in the hands of policy entrepreneurs in controlling the scope and direction of policy change. ${ }^{102}$ Hence in France a "professional armed forces advocacy

\footnotetext{
${ }^{94}$ Elizabeth Kier, "Culture and Military Doctrine: France Between the Wars," International Security 19, no.4 (winter 1995): 65-93; Elizabeth Kier, Imagining War: French and British Military Doctrine between the Wars (Princeton: Princeton University Press, 1997).

${ }^{95}$ Kier, "Culture and Military Doctrine: France Between the Wars," 68; Kier, Imagining War: French and British Military Doctrine Between the Wars, 31.

${ }^{96}$ Dalgaard-Nielsen, Germany, Pacifism and Peace Enforcement, 10-11.

${ }^{97}$ Berger, Cultures of Anti-Militarism: National Security Cultures in Germany and Japan; Duffield, World Power Forsaken: Political Culture, International Institutions and German Security Policy, 261; Johnson, "Thinking About Strategic Culture," 34; Longhurst, Germany and the Use of Force: The Evolution of German Security Policy, 1990-2003, 13; 17.

${ }^{98}$ On the structure agency debate and new institutionalism, see Colin Hay and Daniel Wincott, "Structure, Agency and Historical Institutionalism," Political Studies 44, no.5 (autumn 1996):936-57; on "multiple streams', see John W. Kingdon, Agendas, Alternatives and Public Policy (New York: Harper Collins, 1995), 110 and Nicolaos Zahariadis "Ambiguity, Time and Multiple Streams", in Theories of the Policy Process ed. Paul A. Sabatier (Boulder: Westview, 1999): 73-97; on the ACF, see Sabatier, "The Advocacy Coalition Framework: An Assessment," 117-66.

${ }^{99}$ Irondelle, "Civil-Military Relations and the End of Conscription in France," 170-71.

${ }^{100}$ Irondelle, "Civil-Military Relations and the End of Conscription in France,"; Kingdon, Agendas, Alternatives and Public Policy, 110; Zahariadis, "Ambiguity, Time and Multiple Streams".

${ }^{101}$ Irondelle, "Civil-Military Relations and the End of Conscription in France," 170-71.

${ }^{102}$ Sabatier, "The Advocacy Coalition Framework: An Assessment," 145.
} 
coalition' provided the 'innovative options' on which the Chirac was able to act as a policy entrepreneur. ${ }^{103}$

Longhurst and Dalgaard-Nielsen also emphasize the dynamic nature of strategic culture. ${ }^{104}$ Such accounts argue that policy change reflects the role played by policy leaders and 'political-military elite voices within the national strategic community' 105 as 'political/norm entrepreneurs' ${ }^{106}$ or 'strategic culture agents'. ${ }^{107}$ In accordance with Anthony Gidden's 'Theory of Structuration', change is dependent upon the ability of actors within the political executive and broader defense and security policy subsystem to 'create culture', altering 'peripheral' and 'operational' beliefs through the control of legitimate discourses on defense and security policy and in using such discursive tools to 'rise above the culture they are socialized into and actively attempt to manipulate it'. ${ }^{108}$ This normative entrepreneurship by the 'gatekeepers' and 'agenda-setters' of a strategic culture re-defines actors' perceptions of their interests by refashioning the institutional rules and cognitive paradigms that persist within society and the institutions involved in defense policy agenda-setting and implementation. ${ }^{109}$

The concept of strategic culture overlaps with the work of the Copenhagen School (CS) on 'securitization'. Whilst the CS starts with the realist understanding of security as an exceptional realm, changes to the objectives of defense policy emerge from normative processes. The extent to which an issue is identified as a security threat depends upon the role of "securitizing actors" ${ }^{110}$ in defining an issue that is already "politicized" 111 as a threat to one or more 'referent objects'. ${ }^{112}$ Hence the re-definition of security threats takes

\footnotetext{
${ }^{103}$ Irondelle, "Civil-Military Relations and the End of Conscription in France," 170.

${ }^{104}$ Longhurst, Germany and the Use of Force: The Evolution of German Security Policy 1990-2003, 22; Dalgaard Nielsen, Germany, Pacifism and Peace-Enforcement.

${ }^{105}$ Longhurst, Germany and the Use of Force: The Evolution of German Security Policy 1990-2003, 21.

${ }^{106}$ Dalgaard Nielsen, Germany, Pacifism and Peace-Enforcement, 11; 20.

${ }^{107}$ Longhurst, Germany and the Use of Force: The Evolution of German Security Policy 1990-2003, 22.

108 See Dalgaard Nielsen, Germany, Pacifism and Peace Enforcement, 11-13. As Dalgaard-Nielsen, Longhurst and Sabatier demonstrate, it is highly-difficult for policy actors to directly challenge 'central' (Dalgaard Nielsen, 2006: 13), 'foundational' (see Longhurst, Germany and the Use of Force: The Evolution of German Security Policy 1990-2003, 17) or 'deep-core' (see Sabatier, "The Advocacy Coalition Framework: An Assessment," 133) beliefs. However, they can, over time, alter 'secondary' and 'operational' aspects (see Sabatier, "The Advocacy Coalition Framework: An Assessment," 133) - which Longhurst terms 'security policy standpoints' and 'regulatory practices' and Dalgaard-Nielsen terms 'operational' and 'peripheral' beliefs - contributing over the longer-term, to change to central, foundational or deep-core beliefs.

${ }^{109}$ Dalgaard-Nielsen, Germany Pacifism and Peace Enforcement, 12-13; Longhurst, Germany and the Use of Force: The Evolution of German Security Policy 1990-2003, 22; Fischer, Reframing Public Policy: Discursive Politics and Deliberative Practises, 30-31; John Glenn, Darryl Howlett and Stuart Poore, "Conclusion", in Neorealism versus Strategic Culture, ed. John Glenn et al (Aldershot: Ashgate, 2004), 233.

${ }^{110}$ Securitizing actors include political leaders, bureaucracies, governments, lobbyists and pressure groups, though in democracies, governments tend to enjoy an advantage, stemming from their legitimacy. Buzan, et al, Security: A New Framework for Analysis, 40.

111 'Part of public policy, requiring government decision and resource allocations'. Buzan et al, Security: A New Framework for Analysis, 23.

112 Referent objects include 'things that are seen to be existentially threatened and that have a legitimate claim to survival' (the state, national sovereignty, ideology, national economies, collective identities and habitats), Buzan et al, Security: A New Framework for Analysis.
} 
place through an act of 'securitization', 113 drawing an issue into the realm of exceptionality. At the heart of this process lies the 'speech act' - the use of discourse to convincingly articulate a new issue in security terms as an existential threat to 'referent objects' to the public and the defense and security policy subsystem.

However, the CS has been criticized for its 'internalist', Derridian position - the assumption that speech acts have productive power and the ability to cause, change and found new structures of significance in social relations. ${ }^{114}$ Stritzel argues in favor of an 'externalist' position - that closer attention must be paid to the 'social sphere' within which the 'speech act' takes place. ${ }^{115}$ The success of a 'speech act' will be determined by three forces - the performative power of the articulated threat; its embeddedness within existing discourses and the positional power of the actors who influence the process of defining meaning. ${ }^{116}$ As Stritzel states: 'It is their embeddedness in social relations of meaning and power that constitutes both actors and speech acts', moving the securitization literature towards a focus on the extent to which actors are able to work within the pre-existing cultural context, to determine how international issues are perceived. ${ }^{117}$ Despite its more recent emphasis upon the role of agency and discourse in reshaping belief systems, strategic culture offers a strongly 'externalist' account of 'securitization'. It suggests that the social context within which 'securitizing actors' operate is more restrictive than Buzan et al posit, offering less scope for the identification of new issues as security threats, playing a decisive role in shaping the objectives of defense policy, the appropriate policy instruments and military capabilities.

In her focus on organizational culture, Kier argues that in order to understand changes to military doctrine, closer attention must be paid to civil-military relations change is dependent upon the level of civilian consensus on the domestic role of the armed forces: "the greater the civilian consensus about the position of the military in the state, the more likely it is that international threats and opportunities will shape their decisions'. ${ }^{118}$

Normative approaches lead us to believe that divergence in national preferences on institutional forums should be understood as the product of norms rooted in 'founding moments' - formative experiences or 'critical junctures' - and in long-term socialization processes consequent upon participation in international institutions. ${ }^{119}$ Culturalists who emphasize longer-term convergence in British, French and German preferences on institutional forums argue that this is not only a product of systemic incentives, but also reflects 'norm convergence' and the internalization of common values. ${ }^{120}$ Normative convergence is a product of policy-learning processes consequent upon interaction

\footnotetext{
${ }^{113}$ Defined by Buzan et al as 'the move that takes politics beyond the established rules of the game'. Buzan et al, Security: A New Framework for Analysis, 23.

114 Balzacq, "The Three Faces of Securitization: Political Agency, Audience and Context," 171-201; Stritzel, "Towards A Theory of Securitization: Copenhagen and Beyond," 357-83.

${ }^{115}$ Stritzel, "Towards A Theory of Securitization: Copenhagen and Beyond," 365.

${ }^{116}$ Stritzel, "Towards A Theory of Securitization: Copenhagen and Beyond," 370.

117 Stritzel, "Towards A Theory of Securitization: Copenhagen and Beyond," 367.

${ }^{118}$ Kier, Imagining War: French and British Military Doctrine between the Wars, 141.

${ }^{119}$ Longhurst, Germany and the Use of Force: The Evolution of German Security Policy 1990-2003, 17.

${ }^{120}$ Jones, The Rise of European Security Cooperation, 218; Howorth, Security and Defence Policy in the European Union, 188; Christoph Meyer, The Quest for a European Strategic Culture: Changing Norms on Security and Defence in the European Union (Basingstoke: Palgrave Macmillan, 2006), 11.
} 
through joint military operations and 'elite socialization' within EU and NATO institutional forums, leading to the gradual convergence of domestic norms concerning the objectives and instruments of defense policy and the development of a 'European strategic culture'. ${ }^{121}$ The contradictory nature of the relationship between the EU and NATO - both complementary and overlapping - lies in the piecemeal, evolutionary and gradual nature of norm convergence. ${ }^{122}$ As Meyer argues: 'Normative convergence in these areas does not mean that national beliefs have become fully compatible... only that differences have narrowed'. ${ }^{123}$

Hence the cultural turn in strategic studies, whilst subject to internal contestation, argues that temporal location, sequencing and pace of military reform is determined by norms which are institutionally and societally-embedded and emphasizes the impact of historical experience and collective memory in determining policy choices. ${ }^{124}$ These norms constitute the identities of actors and form 'tool kits of action', mediating systemic pressure and displaying a high-degree of inertia. ${ }^{125}$ In cases of 'misfit' between the changing international security environment and domestic norms, convergence is either rapid and 'fundamental' (in the case of a critical juncture), or incremental, taking the form of fine-tuning. ${ }^{126}$ However, change to the 'cultural core' is not simply the product of structural factors or 'historical pressures' ${ }^{127}$ but depends upon the role of political leaders in the core executive and actors within the broader defense and security policy subsystem as political entrepreneurs/securitizing actors on behalf of cognitive change ${ }^{128}$ or upon 'civilian' consensus concerning the domestic role of the armed forces. ${ }^{129}$

However, the following section will demonstrate that military policy and the temporality of reform processes cannot be fully explained through cultural approaches. A normative analysis is unable to provide a convincing explanation of the divergent temporal location of 'third-order' military reform in the UK (1997-98) and France (199496). The strong civilian consensus on the domestic role of the armed forces in the UK and institutionally and societally-embedded norms concerning the military's (low-high intensity) global role in crisis-management and prevention would lead one to expect reform at an earlier, or at least similar, 'temporal location' than France, where 'third-

\footnotetext{
${ }^{121}$ Cornish and Edwards, "The Strategic Culture of the EU: A Progress Report,"; Howorth, Security and Defence in the European Union, 188; Jones, The Rise of European Security Cooperation, 218; Christoph Meyer, "Convergence towards a European Strategic Culture," European Journal of International Relations 11, no.4 (winter, 2005): 536; Meyer, The Quest for a European Strategic Culture: Changing Norms on Security and Defence in the European Union.

${ }^{122}$ Howorth, Security and Defence in the European Union, 191.

${ }^{123}$ Meyer, The Quest for a European Strategic Culture, 11.

${ }^{124}$ On contestation within the concept of strategic culture, see: Johnson, "Thinking About Strategic Culture,"36-43; Longhurst, Germany and the Use of Force: The Evolution of German Security Policy, 1990-2003, 8-16.

${ }^{125}$ Dalgaard-Nielsen, Germany, Pacifism and Peace Enforcement, 12-13; Colin Grey, "Strategic Culture as Context: The First Generation of Theory Strikes Back," Review of International Studies 25, no.1 (spring 1999): 49-69; Irondelle, "Civil-Military Relations and the End of Conscription in France," 176.

${ }^{126}$ Longhurst, Germany and the Use of Force: The Evolution of German Security Policy, 18.

${ }^{127}$ Berger, Cultures of Anti-Militarism: National Security Cultures in Germany and Japan, 16-21.

${ }^{128}$ Dalgaard-Nielsen, Germany, Pacifism and Peace Enforcement, 11-13; Longhurst, Germany and the Use of Force: The Evolution of German Security Policy 1990-2003, 20-22; Stritzel, "Towards a Theory of Securitization: Copenhagen and Beyond," 257-83.

${ }^{129}$ Kier, Imagining War: French and British Military Doctrine between the Wars, 141.
} 
order' change was delayed by a 'path dependent' commitment to conscription. ${ }^{130}$ It is also difficult to explain the slow pace of British reforms (14 months), given such an 'enabling' normative context. This is all the more perplexing when compared to the pace of the 2003 reform to policy objectives in Germany (6 months). Cultural accounts imply that the German 'culture of anti-militarism' should have ensured a more incremental pace of reform than in the UK due to societal and institutional resistance to radical reform to policy objectives and changes to the 'settings' of the policy instrument.

Instead we must look to the causal role played by material power relationships at the international level and the intervening role of domestic power relationships - to international structure and executive autonomy.

\section{Testing Neoclassical Realist and Cultural Approaches to Convergence and Divergence}

\section{Germany: Domestic Constraint and the Temporal Management of Reform}

Over the 1990s German policy makers have promoted an increasingly active role for the Bundeswehr. Chancellor Helmut Kohl and Defense Minister Volker Rühe (1992-98) used the 1991 Gulf War and 1994 Srebrenica Massacre to legitimate widening the remit of German military action from its Cold War role of territorial and alliance defense to force projection. This culminated in the 12 July 1994 Constitutional Court Ruling, permitting German troops to operate outside NATO's geographical boundaries. Yet the CDU/CSU 1994 'Conceptual Guidelines for the Further Development of the Bundeswehr', developed by Rühe, proposed minimal restructuring, downsizing the military from 370,000 including 170,000 conscripts (the upper ceiling of troops numbers set by the Two Plus Four Treaty of 1990) to 340,000 with 140,000 conscripts and retained territorial defense as the core task of the Bundeswehr.

The 'Cornerstones of a Fundamental Renewal' reform of SPD Defense Minister Rudolf Scharping (1998-2002) of June 2000 also outlined only first-order change to the 'settings' of policy, reducing the military to 277,000 , including 77,000 conscripts. This was surprising, particularly given the suggestions of an independent Commission, known as the 'Weizsäcker Commission', set up by the SPD/Green Government to review the tasks and structure of the Bundeswehr. The Commission's Report (May 2000) codified the lessons of the Kosovo conflict, recommending radical structural and doctrinal reform: crisis-management as the Bundeswehr's core objective and a force of 240,000 with 30,000 conscripts, in order to ensure that Germany would be able to effectively contribute rapid reaction forces to the December 1999 Helsinki Headline Goals (HHG) and the pooling of European military capabilities. ${ }^{131}$

Only in 2003 did SPD Defense Minister Peter Struck (2002-05) abandon territorial defense in favor of expeditionary crisis-management and prevention as part of the 'worldwide fight against international terrorism', Germany would now be 'defended on the Hindukush'. ${ }^{132}$ The reform removed the distinction between a low-readiness Main

\footnotetext{
${ }^{130}$ Irondelle, "Civil-Military Relations and the End of Conscription in France," 157-87.

${ }^{131}$ Gemeinsame Sicherheit und Zukunft der Bundeswehr: Bericht der Kommission an die Bundesregierung, (Bundesministerium der Verteidigung: May 2000).

132 “Wir Müssen die Landesverteidigung neu Definieren,” Süddeutsche Zeitung, 4 February 2004.
} 
Defense Force (MDF) of 279,000 troops for territorial defense and a Crisis Reaction Force (CRF) of 53,600 troops for peacekeeping - created in 1992 by Defense Minister Gerhard Stoltenberg (1989-1992) and retained by Rühe and Scharping. ${ }^{133}$ In its place, Struck developed a 35,000-strong 'rapid reaction force', designed for higher-intensity expeditionary warfare operations; 70,000 stabilizing troops for low- to medium-intensity post-conflict reconstruction/peacekeeping missions and 147,500 support/logistical forces. ${ }^{134}$ Commanded by a single Chief of Staff and a Joint Command Headquarters), the 'rapid reaction force', combined with Struck's strengthening of the Special Operations Division (KSK), (first established under Rühe in 1996) as the 'spearhead force of the new Bundeswehr,' represents an important first step towards convergence with the British Joint Reaction Force and French EMF model. ${ }^{135}$ The creation of a Joint Operations Command (Einsatzrat) is an important step towards the centralization of Bundeswehr command structures, a trend that started with the development of the German Army Operational Command in 1994 and has accelerated over the post-Cold War era, mirroring developments in the UK and France. ${ }^{136}$ The shift to full-spectrum tasks in the support of crisis-management and prevention, the fight against international terrorism and the proliferation of WMD was reinforced by the 2006 Defense White Paper. ${ }^{137}$

However, despite these developments, Germany is not a case of 'third-order' change. The retention of 50,000 conscripts is not only a practical impediment to the development of an expeditionary capacity, but also a financial burden, when funds are required for investment in high-technology capabilities to permit force projection, limiting Germany's ability to contribute to medium-high intensity operations and the extent to which it is possible to undertake even partial convergence around the US-led RMA. ${ }^{138}$ These deficits in investment have been compounded by the comparatively late temporal location of Germany's shift from territorial defense to 'crisis-management' (that has led to investment in inappropriate capabilities) and tight restrictions on defense spending. ${ }^{139}$

Cultural accounts of policy change dominate the literature on German military reform. Longhurst emphasizes the role of 'path dependency' and strategic culture in

\footnotetext{
${ }^{133}$ Longhurst, Germany and the Use of Force: The Evolution of German Security Policy 1990-2003, 102; Elinor C. Sloan, The Revolution in Military Affairs: Implications for Canada and NATO (Kingston/Montreal: McGill Queens Press, 2002): 74.

${ }^{134}$ Dalgaard-Nielsen, Germany, Pacifism and peace Enforcement, 123-24.

${ }^{135}$ King, "Towards a Transnational Europe: The Case of the Armed Forces," 327.

${ }^{136}$ Dalgaard-Nielsen, Germany, Pacifism and peace Enforcement, 134; Longhurst, Germany and the Use of Force: The Evolution of German Security Policy 1990-2003, 101.

137 The White Paper outlines in bold terms how the reformed Bundeswehr would allow Germany to 'actively shape its environment' and 'take preventative action against risks and threats to German security'. White Paper on German Security Policy and the Future of the Bundeswehr, (Federal Ministry of Defense, 2006).

${ }^{138}$ Dalgaard-Nielsen, Germany, Pacifism and peace Enforcement, 126; Dyson, The Politics of German Defence and Security: Policy leadership and Military Reform in the Post-Cold War Era, 111; Lungu, “"'Military Modernization and Political Choice: Germany and the US-Promoted Military Technological Revolution During the 1990s," 261-72; Sperling, "Capabilities Traps and Gaps: Symptom or Cause of a Troubled Trans-Atlantic Relationship?" 457.

${ }^{139}$ Kerry Longhurst and Alistair Miskimmon, "Same Challenges, Diverging Responses: Germany, the UK and European Security," German Politics 16, no.1 (spring 2007): 91.
} 
explaining German commitment to Cold War policy instruments (notably conscription), determining the sequencing of German reform (reform to the policy objectives followed by only partial reform to the policy instrument). ${ }^{140}$ Maull and Berger point to 'the German 'culture of anti-militarism' in informing the objectives of defense policy and temporal location of the shift towards expeditionary crisis-management. ${ }^{141}$ This has formed a powerful normative structural constraint on the willingness and ability of political figures to enact policy change, disincentivizing the 'securitization' of new issues and the development of new defense policy objectives. ${ }^{142}$ Entrepreneurial action by political leaders on behalf of a 'crisis consciousness' or 'norm entrepreneurship' on behalf of a more 'interventionist' role for the armed forces, force projection and a professional military, is associated with great political risk. ${ }^{143}$

However, a focus on neoclassical realism and executive autonomy provides a more convincing account of the process and outcome of reform. The nature of Germany as a federal 'negotiation' democracy increases the sensitivity of the core executive to the politics of base closures. ${ }^{144}$ Combined with the close linkages between financial, budgetary and social policy in the form of the large number of conscientious objectors providing cheap labor to an overstretched social system, this creates a powerful constraint on the ability and willingness of figures within the core executive to undertake 'strategic leadership', promote new policy ideas (crisis-management/prevention and a professional Bundeswehr) and respond to the changing international security environment. ${ }^{145}$ This suggests that executive autonomy, rather than the normative constraints of strategic culture and 'social sphere' in which a 'speech act' is embedded, forms the key determinant of the success of a securitizing act, by incentivizing policy leaders to champion 'securitization' processes in the first place. ${ }^{146}$

These interlinked policy subsystems led to an interest by the powerful German Finance Ministry under Theo Waigel (1989-98) and Hans Eichel (1999-2005), in the promotion of policy stasis on the instruments of defense policy (conscription) due to the negative repercussions of 'third-order' change for German adherence to EMU's Stability

${ }^{140}$ Longhurst, Why Aren't the Germans Debating the Draft? Path Dependency and the Persistence of Conscription, 147-65; Longhurst, Germany and the Use of Force: The Evolution of German Security Policy 1990-2003, 150.

${ }^{141}$ Berger, Cultures of Anti-Militarism: National Security Cultures in Germany and Japan; H. Maull, “Germany's Foreign Policy post-Kosovo: Still a Civilian Power?” Survival 42, no.2 (summer 2000): 91-10.

${ }^{142}$ Stritzel, "Towards a Theory of Securitization: Copenhagen and Beyond," 365.

${ }^{143}$ See Dalgaard-Nielsen, Germany, Pacifism and Peace Enforcement, 144; Longhurst, Germany and the Use of Force: The Evolution of German Security Policy 1990-2003, 147. Post-Cold War unity amongst both 'catch-all parties', the SPD and CDU/CSU on the 'citizen in uniform' as a key element of 'Innere Führung' makes it difficult to apply Kier's analytical framework, for despite this civilian unity, international threats and opportunities appear to play a lesser role in shaping military doctrine than in France and the UK. See Sameera Dalvi, "Germany", in Neorealism Versus Strategic Culture, ed. John Glenn et al (Aldershot: Ashgate, 2004), 204-24; Longhurst, "Why Aren't The Germans Debating the Draft? Path Dependency and the Persistence of Conscription in Germany," 147-65; Kier, Imagining War: French and British Military Doctrine Between the Wars, 4.

${ }^{144}$ Klaus Armingeon, "The Effects of Negotiation Democracy: A Comparative Analysis," European Journal of Political Research 41, no.1 (spring 2002): 90; Dyson, "German Military Reform 1998-2004: Leadership and The Triumph of Domestic Constraint Over International Opportunity," 365.

${ }^{145}$ Dyson, The Politics of German Defence and Security: Policy Leadership and Military Reform in the Post-Cold War Era, 62-66.

${ }^{146}$ Stritzel, "Towards a Theory of Securitization: Copenhagen and Beyond," 362. 
and Growth Pact and budget consolidation. ${ }^{147}$ 'Executive autonomy' is further compromised by the diffusion of competencies on defense policy within the core executive. Whilst the Chancellor plays a central role in formulating general defense policy guidelines (the Kanzlerprinzip), the Defense Minister emerges as crucial in the implementation of policy and in controlling the scope and temporality of policy change (the Ressortprinzip). ${ }^{148}$

The German case draws our attention to a key weakness of the literature on strategic culture: that culture is not a stand-alone variable, but instead can be a tool in the hands of political leaders in the core executive who are preoccupied with domestic politics - the ramifications of reform for the electoral success of their political party and personal political ambitions. ${ }^{149}$ This implies the instrumental use of culture by political elites in the domestic political and temporal management of reform, opening cultural approaches to attack from neoclassical realism for 'conflating mind and matter'. ${ }^{150}$ Crucially, it points to the central role of 'executive autonomy' and domestic material power relationships in explaining the temporality of patterns of convergence around systemic imperatives.

Although Rühe exhibited an activist leadership role in responding to the imperatives of the international security environment and expanding the objectives of defense policy in the initial post-Cold War period, he hesitated in translating this into reforms to the objectives and instruments of defense policy once his domestic strategic room for maneuver narrowed. Kohl and Rühe identified electoral dangers in structural reforms to the Bundeswehr in 1993-94 when the prospects for the government in the forthcoming federal elections looked bleak. ${ }^{151}$

Faced with a slow-down in the German economy and the threat of unrest within the $\mathrm{CDU} / \mathrm{CSU}$ and electorate at the prospect of widespread base closures, Rühe instituted a 'Denkverbot' (ban on thinking) within the Defense Ministry on issues of doctrinal or structural change, providing 'institutional protection' to territorial defense and conscription. ${ }^{152} \mathrm{He}$ appointed conservative officials within the Ministry to act as 'gatekeepers' to the flow of policy ideas, blocking policy-learning processes about the inadequacies of a conscript force and territorial defense. These processes were beginning to take root within the ministry in the context of the changing security environment and Bundeswehr missions in the Adriatic (1992-96), Cambodia (1992-93), Somalia (1993-94)

\footnotetext{
${ }^{147}$ Dyson, The Politics of German Defence and Security: Policy Leadership and Military Reform in the Post-Cold War Era, 94-101.

${ }^{148}$ German Basic Law, Article 65a, 115b; Renate Mayntz, "Executive Leadership in Germany", in Presidents and Prime Ministers, eds. Richard Rose and Ezra N. Suleimann (Washington: American Enterprise Institute Studies, 1980), 142-3.

${ }_{149}$ Dyson, "German Military Reform 1998-2004: Leadership and The Triumph of Domestic Constraint Over International Opportunity," 362; Dyson, The Politics of German Defence and Security: Policy Leadership and Military Reform in the Post-Cold War Era, 94-101.

${ }^{150}$ Rynning, "Shaping Military Doctrine in France: Decisionmakers Between International Power and Domestic Interests," 90.

${ }^{151}$ Dyson, The Politics of German Defence and Security: Policy Leadership and Military Reform in the Post-Cold War Era, 62-66.

${ }^{152}$ Dyson, the Politics of German Defence and Security: Policy Leadership and Military Reform in the post-Cold War Era, 66-68.
} 
and Bosnia (1993-95). ${ }^{153}$ The narrowing of 'executive autonomy' in defense policy incentivized Rühe's promotion of 'stasis' rather than 'strategic innovation' in his 1994 reform. ${ }^{154}$

Under Scharping the political and temporal management of reform also took the form of actively mediating systemic imperatives for 'third-order' change to the objectives, instruments and institutions of German defense policy, particularly those presented by the 1999 Kosovo War. The implications of the conflict were codified by the Weizsäcker Commission, whose conclusions were marginalized by Scharping, despite the consensus that the policy forum had generated amongst its participants about the need for a military orientated to crisis-management/prevention, a dramatic reduction of conscription and the development of an autonomous European military capability. ${ }^{155}$ Scharping was successful in ensuring policy stasis and impeding policy learning, and exerted a strong measure of control over the context of ideas within which reform took place. He did so by blocking change agents within the policy subsystem and at the macropolitical level to ensure that they did not challenge his veto-role. ${ }^{156}$

The promotion of policy stasis became increasingly difficult to reconcile with Germany's expanding international role during Struck's tenure as defense minister due to the increasing disjuncture between German policy and systemic imperatives. German participation in NATO's ISAF force and the development of NATO's RRF was accompanied by complex and skilful leadership role from Struck in the 2003 reform. Struck combined 'strategic innovation' to the objectives of German defense policy with only partial change to the instruments of defense policy, preventing forces for change from shaping policy. ${ }^{157}$ Strategic culture formed a resource, used selectively by Struck to control the policy process, justifying change to the Bundeswehr's tasks (as crucial to renewing Germany's long-standing commitment to its UN, NATO and EU partners) and impeding change to the structure of the Bundeswehr (by emphasizing the importance of conscription for civil-military relations, the principle of 'innere Führung', (inner leadership) and emphasizing the utility of conscripts in undertaking low-medium intensity peacekeeping operations). ${ }^{158}$ However, as Edmunds and Longhurst demonstrate, professional and specialist forces are an imperative for both peacekeeping and higher-

${ }^{153}$ Dyson, the Politics of German Defence and Security: Policy Leadership and Military Reform in the post-Cold War Era, 112.

${ }^{154}$ Dyson, The Politics of German Defence and Security: Policy Leadership and Military Reform in the post-Cold War Era, 62-68; Lungu, "Military Modernization and Political Choice: Germany and the USPromoted Military Technological Revolution During the 1990s," 264.

${ }^{155}$ Dalgaard-Nielsen, Germany, Pacifism and Peace Enforcement, 123; Dyson, "German Military Reform 1998-2004: Leadership and the Triumph of Domestic Constraint Over International Opportunity," 364; Longhurst, Germany and the Use of Force: The Evolution of German Security Policy 1990-2003, 104.

${ }^{156}$ Dyson, "German Military Reform 1998-2004: Leadership and the Triumph of Domestic Constraint Over International Opportunity," 369; Dyson, The Politics of German Defence and Security: Policy Leadership and Military Reform in the post-Cold War Era, 101-112.

${ }^{157}$ Dyson, "German Military Reform 1998-2004: Leadership and the Triumph of Domestic Constraint Over International Opportunity," 377-80; Longhurst, Germany and the Use of Force: The Evolution of German Security Policy 1990-2003, 113-15.

${ }^{158}$ Dyson, "German Military Reform 1998-2004: Leadership and the Triumph of Domestic Constraint Over International Opportunity," 371; Dyson, The Politics of German Defence and Security: Policy Leadership and Military Reform in the post-Cold War Era, 136-40. 
intensity expeditionary operations. ${ }^{159}$ Hence in the context of the ISAF mission and postCold War crisis-management operations undertaken by the Bundeswehr, opposition to conscription within the Defense Ministry began to mount, with several Generals calling for 'highly-trained fighters' and expressing their bitterness about the role of Zivildienst in producing policy stalemate. ${ }^{160}$

As Rynning argues, policy leadership emerges as an important unit-level variable in shaping the temporal location, sequencing and pace of military reform. ${ }^{161}$ Although Chancellors set the strategic guidelines for policy change, and their support was necessary for the development and implementation of reform, control over the scope and pace of policy change was consequent upon the 'day-to-day' management of the policy sector and ministerial policy leadership (the Ressortprinzip). ${ }^{162}$ Policy change to the doctrine, and particularly structure, of the armed forces depended much on the ability of Rühe, Scharping, and Struck to open-up or block processes of policy learning and political debate, within the policy subsystem and at the macropolitical level, to negotiate constitutional constraints on the role of the Bundeswehr and obtain parliamentary approval for the Bundeswehr's deployment. ${ }^{163}$ This involved close attention to the use of strategic culture as a resource with which to justify their chosen leadership roles and frame policy proposals. ${ }^{164}$

However, the decisive causal factor in determining German divergence in temporality lies not in the execution of policy leadership, but in the deficits in executive autonomy on defense policy to which the Chancellors and Defense Ministers were subject. 'Executive autonomy' explains why the 1994 and 2000 reforms only outlined changes to the 'settings' of policy and the delayed temporal location of reform to the objectives of German defense policy (2003). Executive autonomy also determined the sequencing (reforms only to the settings of the policy instrument) and pace of reform (6 months). Struck was keen to engineer a fait accomplis and close down the possibility for a macro-political debate on reform to the policy instrument in the face of increasing domestic opposition to conscription within the SPD/Green coalition and the development

${ }^{159}$ Edmunds, "What Are Armed Forces For? The Changing Nature of Military Roles in Post-Cold War Europe," 1069; Longhurst, Germany and the Use of Force: The Evolution of German Security Policy, 124.

160 "Ende mit Schrecken," Spiegel, 17 March 2003, A50.

161 Rynning, "Shaping Military Doctrine in France: Decisionmakers Between International Power and Domestic Interests," 85-116.

${ }^{162}$ Dyson, "German Military Reform 1998-2004: Leadership and the Triumph of Domestic Constraint Over International Opportunity," 372-3; Dyson, Dyson, The Politics of German Defence and Security: Policy Leadership and Military Reform in the post-Cold War Era, 188-92.

${ }^{163}$ Both Rühe and Scharping were also keen to avoid alienating powerful regional figures within their parties due to their personal political ambition of the Chancellorship. This further circumscribed their willingness to push through radical base closures and contributed to the careful spatial targeting of base closures and avoidance of large-scale closures in Länder with forthcoming elections. (Dyson, 2007: 104; $108 ; 173)$. The sensitivity of the politics of base closures and the abolition of conscription made the Defense Ministry something of a political graveyard and an unattractive ministerial position, gaining a reputation as a 'Schleudersitz' (ejector seat) (Dyson, 2007: 229).

On Rühe and constitutional constraints see Dyson, 2007: 59-61; on Rühe, the Bundestag and the deployment of troops see Dyson, 2007: 61; on Struck and negotiating constitutional constraints see Dyson 2005: 376-77.

${ }^{164}$ Dyson, "German Military Reform 1998-2004: The Triumph of Domestic Constraint Over International Opportunity," 361-86; Dyson, The Politics of German Defence and Security: Policy Leadership and Military Reform in the post-Cold War Era, 80-81; 189-92. 
of a 'mature' advocacy coalition championing an end to conscription. ${ }^{165}$ The pace of reform to the objectives of policy and its specific temporal location (at the beginning of the 2002-06 legislative period) also reflected the SPD's concern to implement the base closures consequent upon a 35,000 troop reduction well in advance of the next Federal elections. $^{166}$

The institutional forums of German defense policy continue to cohere around the traditional German 'bridge' role, between British/U.S. and French preferences. ${ }^{167}$ Indeed, it is possible to identify a 'bi-furcation' ${ }^{168}$ within the Federal Executive, between a highly-Europeanist and active Foreign Ministry in 'uploading' German preferences to ESDP and an 'Atlanticized' Defense Ministry, more reactive and resistant to the anchoring of defense policy within ESDP. ${ }^{169}$

Cultural approaches posit that the German 'bridge role' and 'bi-furcated Federal Executive', split between a 'Europeanized' Foreign Ministry and 'Atlanticized' Defense Ministry, is a consequence of the post-war experience of rehabilitation into the international community and concomitant necessity to negotiate and broker French and U.S. concerns through the EU and NATO respectively. ${ }^{170}$ It also reflects the need to broker agreement between the two dominant advocacy coalitions in Germany defense policy - one Europeanist, centered on the SPD/Greens, the other Atlanticist, embedded within the CDU/CSU and FDP. ${ }^{171}$

However, neoclassical realism provides a more convincing explanation of German preferences on institutional forums than neo-realism or cultural accounts. Whilst 'allied cooperation' over the long-run reflects systemic imperatives, unit-level factors in the shape of domestic material power relationships form important intervening variables. This explains the active role of the German Foreign Ministry in developing ESDP and the

\footnotetext{
${ }^{165}$ Dalgaard-Nielsen, Germany, Pacifism and Peace-Enforcement, 126; Dyson, "German Military Reform 1998-2004: The Triumph of Domestic Constraint Over International Opportunity," 377-85; Longhurst, Germany and the Use of Force: The Evolution of German Security Policy 1990-2003, 133.

${ }^{166}$ Dyson, The Politics of German Defence and Security: Policy Leadership and Military Reform in the post-Cold War Era, 120-22.

${ }^{167}$ Dyson, "German Military Reform 1998-2004: The Triumph of Domestic Constraint Over International Opportunity," 375; Adrian Hyde-Price, Germany and European Order, (Manchester: Manchester University Press, 2000): 205-07.

${ }^{168}$ On the 'bi-fraction' within the German federal executive, see Klaus H. Goetz, "The Federal Executive: Bureaucratic Fusion vs. Governmental Bifurcation", in eds. Kenneth H.F. Dyson and Klaus H. Goetz Germany, Europe and the Politics of Constraint, eds. K.H. Dyson and K.H. Goetz (Oxford: OUP, 2003), 55-72.

${ }^{169}$ Simon Bulmer, Charlie Jeffrey and William Paterson, Germany's European Diplomacy (Manchester: Manchester University Press, 2000), 25.

${ }^{170}$ Hyde-Price, Germany and European Order, 205-09; Alistair Miskimmon and William Paterson, "The Europeanisation of German Foreign and Security Policy: On the Cusp Between Transformation and Accommodation", in Germany, Europe and the Politics of Constraint, ed. Kenneth H.F. Dyson, K.H. and Klaus H. Goetz (Oxford: Oxford University Press, 2003), 325-45.

${ }^{171}$ Lothar Gutjahr, German Foreign and Defence Policy After Reunification, (London: Pinter, 1994), $135-$ 46; Dyson, "German Military Reform 1998-2004: The Triumph of Domestic Constraint Over International Opportunity," 374-75.
} 
Defense Ministry's reactive 'laggard' role in dealing with the implications of ESDP for the objectives and instruments of German defense policy. ${ }^{172}$

Defense Ministers were critical in determining the extent and manner in which German defense policy was Atlanticized and Europeanized. The greater 'institutional credibility' of NATO within the Defense Ministry is more than just a product of 'elite socialization' and 'institutionally-embedded norms'; it stems from the unwillingness of Rühe, Scharping and Struck to appoint or promote pro-Europeanist Vordenker (innovators) within the Defense Ministry for fear of domestic political implications. ${ }^{173}$ This was an attempt by Defense Ministers to avoid the potentially de-stabilizing effects that framing reform within 'allied cooperation' as part of ESDP could have upon the political and temporal management of reform due to the pressure it would create within the Defense Ministry to abolish conscription. This would have implied damaging repercussions for the social and financial policy subsystems and politically-sensitive base closures in the context of a federal system. ${ }^{174}$ In short, the Defense Ministry has been locked into domestic institutional structures that gave little incentive to 'Europeanize' the Bundeswehr and instead promoted the active leadership of Defense Ministers in shaping and using 'Atlanticization' and 'Europeanization' in the interests of their own domestic political agendas. ${ }^{175}$

Conversely, German Foreign Ministers have benefited from a greater level of autonomy in promoting 'allied cooperation' through the EU. This is a consequence, not only of the long-term role of the Foreign Ministry as the senior coordinating Ministry pursuing European integration, but also of Foreign Ministers' status as leaders of smaller coalition partners (until the SPD's Frank-Walter Steinmeier in 2005), reducing their sensitivity to the electoral fall-out of base closures and financial implications of the abolition of conscription. A focus on domestic power relationships helps to explain why both Klaus Kinkel (Liberal Party Foreign Minister 1992-1998) and Joschka Fischer (Green Foreign Minister 1998-2005), concerned with the limitations of territorial defense objectives and a conscript-based policy instrument, sought out (ultimately unsuccessful) roles as 'strategic innovators' on behalf of a professional military, orientated towards crisis-intervention tasks. ${ }^{176}$

Whilst the domestic political implications of the embedding of policy within EU/NATO represent a significant intervening variable impacting on policy choices of institutional venue in the short-medium term, Germany, in line with the UK and France, has become increasingly willing to put its weight behind the development an independent

\footnotetext{
${ }^{172}$ Dyson, The Politics of German Defence and Security: Policy Leadership and Military Reform in the post-Cold War Era, 173-74; Wolfgang Wagner, "From Vanguard to Laggard: Germany in European Security and Defence Policy," German Politics 14, no.4 (winter 2005): 455-69.

${ }^{173}$ Dyson, The Politics of German Defence and Security: Policy Leadership and Military Reform in the post-Cold War Era, 173-74.

${ }^{174}$ Dyson, "German Military Reform 1998-2004: The Triumph of Domestic Constraint Over International Opportunity," 365-69.

${ }^{175}$ Dyson, The Politics of German Defence and Security: Policy Leadership and Military Reform in the post-Cold War Era, 175-77.

${ }^{176}$ Dyson, The Politics of German Defence and Security: Policy Leadership and Military Reform in the post-Cold War Era, 68-71; 95.
} 
capacity for Europe to act autonomously. ${ }^{177}$ This strategic imperative became particularly pressing for Germany in the context of the 2002 US Security Strategy and in the run-up to the 2003 Iraq crisis. ${ }^{178}$ The intensified fear of 'entrapment' or 'abandonment' by the US has led to changes to the objectives of German defense policy in an attempt by Germany to gain greater influence within the U.S. and ensure a measure of European autonomy of action by contributing to the pooling of European military resources, routed through both NATO and ESDP. ${ }^{179}$ Hence in the 2003 Defense Policy Guidelines, Struck framed the changing objectives of German defense policy as a means with which to contribute to the development of an ESDP as the 'European Pillar' of the Atlantic Alliance, thereby strengthening the Bundeswehr's capacity to provide troops for both the NRF and RRF, reinforced by the Grand Coalition's Defense White Paper of $2006 .{ }^{180}$

\section{France: Domestic Incentives and Strategic Innovation}

Until 1994 the objectives of French defense policy were characterized by stasis and the perpetuation of the principles of national strategic autonomy and territorial defense. However, Prime Minister Edouard Balladur instigated a 'revolutionary' reform of defense objectives in the 1994 Defense White Paper. ${ }^{181}$ In the context of complex new security threats, the White Paper outlined a 'paradigm shift' from strategic autonomy, to cooperation as part of NATO and, in particular, through the emerging ESDP, emphasizing the necessity to develop a military capable of 'preventing and managing crises of variable intensity'. ${ }^{182}$

However, it was not until the election of President Jacques Chirac in May 1995 that third-order change was initiated. The reform of 1995-96 built upon the changes to the objectives of defense policy and institutional forums initiated by Balladur. Not only would the role of the armed forces be to impose French or international will through

\footnotetext{
177 Press-Barnathan, "Managing the Hegemon: NATO Under Unipolarity," 304; Michael Brenner, "The CFSP Factor: A Comparison of United States and French Strategies," Cooperation and Conflict 38, no.3 (autumn 2003): 192.

${ }^{178}$ Dyson, The Politics of German Defence and Security: Policy Leadership and Military Reform in the post-Cold War Era, 39-40; Rynning, NATO Renewed: The Power and Purpose of Trans-Atlantic Cooperation, 158-59.

${ }^{179}$ Press-Barnathan, "Managing the Hegemon: NATO Under Unipolarity" 307-08. Struck legitimated the 2003 reform to policy objectives by stating: 'Germany will be defended on the Hindukush' in "Wir müssen die Landesverteidigung neu definieren,” Süddeutsche Zeitung, 4 February 2004.

${ }^{180}$ Dalgaard-Nielsen, Germany, Pacifism and Peace Enforcement, 152; See also White Paper on German Security Policy and the Future of the Bundeswehr, (Federal Ministry of Defense, 2006), 6. In addition, Germany was fearful of the implications of the pursuit of a 'core Europe' on ESDP due to the fear of the implications of a potentially 'bifurcated Europe' for German regional influence amongst East Central European states, Dyson, "German Military Reform 1998-2004: Leadership and the Triumph of Domestic Constraint Over International Opportunity," 376.

${ }^{181}$ Robbin F. Laird and Holger H. Mey, "The Revolution in Military Affairs: Allied Perspectives," McNair Paper, 60 (Institute for National Strategic Studies: Washington, spring 1999), 53-54; Justin J. McKenna, "Towards the Army of the Future: Domestic Politics and the End of Conscription in France," West European Politics 20, no.4 (winter 1997): 125-45.

${ }^{182}$ George A. Bloch, "French Military Reform: Lessons for America's Army?" Parameters: US Army War College Quarterly 30, no.2 (summer 2000): 36; Bastien Irondelle, "Europeanisation without the European Union? French Military Reforms 1991-96," Journal of European Public Policy 10, no. 2 (2003a): 208-26; Irondelle, "Civil-Military Relations and the End of Conscription in France," 157-87.
} 
'coercive force', but also through the 'mastery of violence'. The new military doctrine was designed to ensure that the armed forces could be used as a tool with which to prevent and control the escalation of conflict, employing a 'totality of political, diplomatic, humanitarian and media actions', representing close convergence with the UK's concept of 'defense diplomacy'. ${ }^{183}$

The experience of French participation in the 1991 Gulf War and of peacekeeping during the Wars of Secession in the former Yugoslavia forcefully demonstrated the inadequacies of a reliance on the deterrent power of the Force de Frappe and a conscript army in tackling contemporary global and regional security challenges (Menon 1995; Bloch, 2000). ${ }^{184}$ Hence Chirac proposed radical structural reform, abolishing conscription and streamlining the military from 400,000 to 250,000 (excluding gendarmerie) between 1996 and 2002, increasing the number of forces available for global deployment in support of full-spectrum tasks from 12,000 to 60,0000 . The military was re-structured according to the principle of 'modularity', allowing flexibility in the face of changing security exigencies (Bloch, 2000: 38; Laird and Mey, 1999: 51). This has facilitated the development of specialized units (Joint Reaction Forces) that can be drawn together as a force of between 50-60,000 at short-notice by four Etat Major des Forces (EMF) Headquarters, replacing the division-level commands of the Cold War. ${ }^{185}$

In France, normative accounts emphasize the critical roles played by Edouard Balladur in redefining the objectives of defense policy in the 1994 Defense White Paper and by President Jacques Chirac and Prime Minister Alain Juppe in 'manufacturing culture', by using the Gulf War and French participation in Bosnia to generate a perception of crisis concerning appropriate policy instruments, notably the 'citizen in uniform'. ${ }^{186}$ McKenna (1998) and Irondelle (2003b) argue that Chirac and Juppe, spearheaded an 'advocacy coalition' in favor of a professional military. This initiated policy-learning to institutionally-embedded beliefs on conscription, leading to a new civilian consensus around the domestic role of the armed forces and upon the need for the creation of a professional armed force. ${ }^{187}$ 'Third-order' change could then be implemented despite the preferences of the military for a 'mixed force' of conscripts and professionals, an analysis that also appears to confirm the arguments of Kier (Bloch, 2000). ${ }^{188}$ For Irondelle path dependency forms the decisive variable explaining the pace of reform and the 32 months that elapsed between reform to the objectives and institutional forums of policy and the creation of a professional armed force. ${ }^{189}$ This account has much in common with the 'externalist' securitization account of Stritzel, who argues that closer attention to the social context of the 'speech act' is necessary - in this

\footnotetext{
${ }^{183}$ Patrick Bratton, "France and the Revolution in Military Affairs," Contemporary Security Policy 23, no.2 (autumn 2002): 110; Bloch, "French Military Reform: Lessons for America's Army?" 43; Anthony Forster, Armed Forces and Society in Europe (Basingstoke: Palgrave Macmillan, 2006), 49-50; Ronald Tiersky, "French Military Reform and Restructuring," Joint Force Quarterly 1 (spring 1997): 95-112.

${ }^{184}$ Bloch, "French Military Reform: Lessons For America's Army?" 33-45; Anand Menon, "From Independence to Cooperation: France, NATO and European Security," International Affairs 71, no.1 (1995): 19-34.

${ }^{185}$ King, "Towards A Transnational Europe: The Case of the Armed Forces," 326.

${ }^{186}$ Bloch, "French Military Reform: Lessons For America's Army?" 35.

${ }^{187}$ McKenna, Towards the Army of the Future: Domestic Politics and the End of Conscription in France," $135-36$.

${ }^{188}$ Bloch, "French Military Reform: Lessons For America's Army?" 33-45.

${ }^{189}$ Irondelle, "Civil-Military Relations and the End of Conscription in France," 157-87.
} 
case the social context was highly-restrictive, slowing down policy change. ${ }^{190}$ However, neoclassical realism and a focus on 'executive autonomy' provides a more convincing explanation of patterns of convergence and divergence in the temporality of reform.

The French President enjoys a high-level of autonomy in defense policy, incentivizing strategic innovation on behalf of convergence with systemic imperatives. ${ }^{191}$ This autonomy is a product of the unitary state, nature of military policy as the 'reserved domain' of the President, the low salience of regional and local elections compared to Germany, prolonged window of opportunity open to French Presidents to enact policy change due to the seven year term of office (until 2002) and weak linkages between the social and defense policy subsystems. McKenna states: 'his [the French President] extraordinary powers with regard to national defense weaken the argument that he is obliged to consult with any persons concerned with defense matters'. As will become clear, deficits in this autonomy during cohabitation (1993-95) are a central factor in explaining the pace of 'third-order' reform. ${ }^{192}$

The empirical evidence undermines culturalist arguments that posit the importance of civilian unity over the domestic role of the armed forces in determining convergence with systemic imperatives. ${ }^{193}$ Neither can change be explained by analyzing the role of Chirac as a 'securitizing actor' or 'norm entrepreneur', spearheading an 'advocacy coalition' affecting 'peripheral, operational and central beliefs' of national strategic culture and building civilian consensus around change to the policy instrument. ${ }^{194}$

In 1995 there was little consensus amongst the public concerning an all-volunteer force and only a 'nascent' advocacy coalition promoting the end of conscription. ${ }^{195}$ Whilst the political center-right (UDF and RPR) was broadly in favor of professional forces, the French Left opposed the abolition of conscription. ${ }^{196}$ This 'civilian disunity' was reflected in Assembly complaints that President Chirac had failed to consult MPs and the general public and in public opinion, which was strongly opposed to the abolition of conscription in $1995 .{ }^{197}$ Indeed, even the Defense Minister, Charles Millon, was opposed to a fully-professionalized force. ${ }^{198}$ The all-volunteer force was also a surprise for the military which, in the context of Balladur's 1994 White Paper, had drawn

\footnotetext{
${ }^{190}$ Stritzel, "Towards a Theory of Securitization: Copenhagen and Beyond," 357-83.

${ }^{191}$ Gordon, A Certain Idea of France; McKenna, "Towards the Army of the Future: Domestic Politics and the End of Conscription in France," 138; Rynning, "Shaping Military Doctrine in France: Decisionmakers Between International Power and Domestic Interests," 108.

${ }^{192}$ McKenna, "Towards the Army of the Future: Domestic Politics and the End of Conscription in France," 138.

${ }^{193}$ Kier, Imagining War: French and British Military Doctrine Between the Wars.

194 Dalgaard-Nielsen, Germany, Pacifism and Peace Enforcement, 12-13; Irondelle, "Europeanisation without the European Union? French Military Reforms 1991-96," 208-26; Irondelle, "Civil-Military Relations and the End of Conscription in France," 157-87.

${ }_{195}$ Irondelle, "Civil-Military Relations and the End of Conscription in France," 179-80. Sabatier distinguishes between 'nascent' and 'mature advocacy coalitions. Mature coalitions have a 'line up of allies and opponents that are rather stable over a period of a decade or so', sharing common 'policy core' beliefs. Sabatier and Jenkins-Smith, "The Advocacy Coalition Framework: An Evaluation," 136.

${ }^{196}$ Rynning, "Shaping Military Doctrine in France: Decisionmakers Between International Power and Domestic Interests," 96; 106.

${ }^{197}$ Irondelle, "Civil-Military Relations and the End of Conscription in France," 180; McKenna, "Towards the Army of the Future: Domestic Politics and the End of Conscription in France," 138.

${ }^{198}$ Bloch, "French Military Reform: Lessons For America’s Army?" 36.
} 
up its own model of structural reform under the guidance of General Jean-Rene Bachelet ('The Army of the $21^{\text {st }}$ Century') outlining a 'mixed model' of conscripts and professionals.

The empirical evidence attests not to path dependency as the determinant of the pace of reform (32 months) but points instead to the intervening roles played by domestic power relationships during cohabitation from 1993-95. Under cohabitation Mitterrand lacked several key domestic material power resources in defense policy. Prime Minister Edouard Balladur (RPR) claimed defense policy to be a 'shared domain' necessitating a greater level of compromise in the policy sector. ${ }^{199}$ The forthcoming Presidential elections also provided little incentive for Socialist candidates to act as a 'strategic innovators' and open-up debate about conscription, due to the uncertain electoral benefits of campaigning on behalf of professional armed forces, helping to explain why Chirac 'carefully avoided talking about all-volunteer forces' and 'at no time suggested abandoning conscription' during the 1995 election campaign. ${ }^{200}$

It was only upon the election of Chirac as President in May 1995 that the domestic window of opportunity opened for strategic leadership on reforms to the policy instrument. ${ }^{201}$ The experience of joint operations with the British in the Gulf and Bosnia left Chirac convinced that the British military should be the 'model against which the French would measure themselves' and that professionalization would be the only means with which to operate effectively in the context of the multinational low-high intensity peacekeeping operations, which increasingly characterized French military deployments. ${ }^{202}$ Whilst Chirac's base closures elicited protest, particularly in North-East France, his seven-year term of office and the end of cohabitation allowed him to promote third-order policy change by pointing to the challenges and opportunities presented by the international security environment, the imperative of meeting the Maastricht Convergence Criteria and long-term savings associated with professional armed forces. ${ }^{203}$ Indeed, military reform presented an excellent opportunity for Chirac gain early political credit and profile himself as an innovator. ${ }^{204}$

Chirac's autonomy was further enhanced by the nature of linkages between the social, finance and defense policy subsystems. In Germany the implications of third order reform for social policy encouraged the Finance Ministry under both the Kohl and Schröder governments to militate against convergence with systemic imperatives in order to meet the Maastricht Convergence Criteria. Conversely, the French Finance Ministry enhanced Chirac's autonomy in defense policy: 'The reform of the armed forces in 199596 directly originated in budget cuts...the fundamental issue of the single currency

\footnotetext{
${ }^{199}$ Bloch, "French Military Reform: Lessons For America’s Army?" 35.

${ }^{200}$ Irondelle, "Civil-Military Relations and the End of Conscription in France," 180.

${ }^{201}$ McKenna, "Towards the Army of the Future: Domestic Politics and the End of Conscription in France," 135 .

${ }^{202}$ Laird and Mey, "The Revolution in Military Affairs: Allied Perspectives," 53-55; Sloan, The Revolution in Military Affairs: Implications for Canada and NATO, 68. During the 1990/91 Gulf War the French had only been able to mobilize 12,000 troops for participation in the conflict from a combat ready army of 280,000, whilst the British had mobilized over 30,000 troops from a combat ready force of 160,000. See McKenna, "Towards the Army of the Future: Domestic Politics and the End of Conscription in France," 134.

${ }^{203}$ Tiersky, "French Military Reform and Restructuring," 3.

${ }^{204}$ Bloch, "French Military Reform: Lessons For America’s Army?" 36.
} 
enabled the Treasury to have unprecedented power under the $5^{\text {th }}$ Republic over defense policy,. ${ }^{205}$

Whilst the Finance Ministry supported Chirac's reform agenda, during cohabitation (1993-95) the same institution, led by Edmond Alphandery of the opposition UDF, had employed its 'unprecedented power' to militate against change, acting as a powerful veto-player. As Irondelle demonstrates: 'The Finance Ministry and its powerful Budget Committee favored the continuation of conscription for financial reasons ${ }^{206}$ In addition, the constraints of cohabitation also increased the sensitivity of Mitterrand to opposition to professionalization from the Interior Ministry, led by Charles Pasqua of the Gaullist RPR Party, that benefited from recruits serving in the police force and civil security. ${ }^{207}$ Hence in 1995 Chirac enjoyed not only a clearer picture of systemic imperatives than Mitterrand, but also much greater 'executive autonomy' and incentives for action than the former President had experienced. The protracted sequencing of reform was a reflection of the domestic material power relationships under cohabitation which circumscribed an entrepreneurial leadership role on the abolition of conscription from 1993-95.

Accordingly, the process of 'third-order' reform reflected the 'material' power resources at Chirac's disposal in French defense policy and 'entrepreneurial policy leadership'. This stands in marked contrast to Germany, where Defense Ministers emerge as key figures in the management of reform processes: 'Chirac used all the resources of his policy leadership to ensure the change to a professional army against the wishes of both the armed forces and the Defense Ministry'. ${ }^{208}$ The Presidential proposals for reform were drawn up within a select working group, the Commaunite Stratégique that granted privileged influence to close political confidants of Chirac, such as former Minister of Defense Pierre Messmer. ${ }^{209}$ The Commaunité Stratégique formed the first stage of 'institutional protection', allowing the President to engineer a fait accomplis and marginalize any potential opposition within the broader political system, particularly the Left.

Chirac was able to overcome resistance to strategic innovation within the Defense Ministry by providing further 'institutional protection' to 'third-order' change through the Defense Ministry's Strategic Affairs Division (SAD) that had been strengthened under Balladur and Pierre Joxe (Defense Minister 1991-1993). Joxe had recognized the necessity for an empowered Chief of Staff and a horizontal organization of the military, rather than vertical, separate services, allowing greater military-political cooperation in the context of out-of-area and low-medium-intensity operations. ${ }^{210}$ The SAD was also closely aligned with the Foreign Ministry, a strong supporter of a professional force,

\footnotetext{
${ }^{205}$ Irondelle, "Europeanisation without the European Union? French Military Reforms 1991-96,” 219-20.

${ }^{206}$ Irondelle, "Civil-Military Relations and the End of Conscription in France," 177-78.

${ }^{207}$ Irondelle, "Civil-Military Relations and the End of Conscription in France," 178.

${ }^{208}$ Irondelle, "Civil-Military Relations and the End of Conscription in France," 182.

${ }^{209}$ Bloch, "French Military Reform: Lessons For America’s Army?" 36.

210 Bloch, "French Military Reform: Lessons For America's Army?" 36; Rynning, "Shaping Military Doctrine in France: Decisionmakers Between International Power and Domestic Interests,” 110.
} 
acting as a 'broker' of change within the Defense Ministry. ${ }^{211}$ Hence Chirac was able to compel the Chiefs of Staff and Military to professionalize the military. ${ }^{212}$

The President's decisive 'strategic innovation' and the 'institutional protection' afforded by the SAD allowed him to delegate the technical details of force structure to the military. ${ }^{213}$ This laissez-faire approach to force structure contrasts markedly to Germany, where the federal system and powerful regional politicians incentivize acute concern with the detail of force structures and spatial targeting of troop reductions, in order to minimize the political impact of base closures. ${ }^{214}$ 'Executive autonomy' ensured that Chirac could leave the detail of reform to the military, confident in appropriate change to the policy instrument and in his ability to implement the reform model. ${ }^{215}$ It is also important to note that Chirac's strategic innovation was seized upon by military planners as an opportunity to renew France's strategic importance. ${ }^{216}$ These factors combined to inform the military's development of an enhanced force projection capability and embrace new doctrine (the 'mastery of violence'), in addition to the more traditional 'coercion by the means of force', as its two key operational modes.

According to cultural explanations of policy change, the post-Cold War shift from 'national sanctuary' to the 'Europeanization' of French defense policy is a product of 'socialization processes' to which the French elite were subject at the European level. ${ }^{217}$ Such accounts also draw attention to the central roles of President Jacques Chirac and Prime Minister Alain Juppe as 'norm entrepreneurs' in developing a sense of crisis consciousness and promoting policy-learning concerning the failure of 'splendid isolation' and, in its place, championing an advocacy coalition that promoted a Europeanized military policy. This resulted in 'paradigm change' to the cognitive and normative elements of French defense policy making. ${ }^{218}$ Culturalists posit that the sequencing and temporal location of French changes to the institutional forums of defense policy (1994), that preceded reform to the objectives of policy, reflect the identification and resonance of ESDP with deeply-embedded Gaullist norms concerning the role of France as a 'Third Force' in international politics and the 'Europeanization' of French exceptionalism. This has been a hallmark of Chirac's discourse on ESDP. ${ }^{219}$ As Chirac stated of the ESS: [The ESS Represents] A Europe which...places at the heart of

${ }^{211}$ Irondelle, "Europeanisation without the European Union? French Military Reforms 1991-96," 220.

${ }^{212}$ Irondelle, "Civil-Military Relations and the End of Conscription in France," 183; Laird and Mey, "The Revolution in Military Affairs: Allied Perspectives," 53.

${ }^{213}$ Bloch, "French Military Reform: Lessons For America’s Army?" 36-39.

214 Dyson, The Politics of German Defence and Security: Policy Leadership and Military Reform in the Post-Cold War Era, 63-65.

${ }^{215}$ Bloch, "French Military Reform: Lessons For America's Army?" 36.

${ }^{216}$ McKenna, "Towards the Army of the Future: Domestic Politics and the End of Conscription in France," 136.

${ }^{217}$ Irondelle, "Europeanisation without the European Union? French Military Reforms 1991-96," 208-26; Pernille Riecker, "From Common Defence to Comprehensive Security: Towards the Europeanization of French Foreign and Security Policy?" Security Dialogue 37, no.4 (winter 2006): 525.

${ }^{218}$ Irondelle, "Europeanisation without the European Union? French Military Reforms 1991-96," 222.

${ }^{219}$ Martin Marcussen, Thomas Risse, Daniela Engelmann-Marin, Hand Joachim Knopf and Klaus Roscher "Constructing Europe: The Evolution of British, French and German Nation-State Identities," Journal of European Public Policy 6, no.4 (winter 1999): 619-22. 
everything it does respect for a number of principles... which constitute both a French Republican Codes of Ethics... and a shared code of ethics of Europe'. ${ }^{20}$

However, in order to understand why French changes to institutional forums took place at such a comparatively early temporal location (1994), a focus on specific features of French 'external vulnerability' is critical. The 'Europeanization' agenda outlined by Balladur was not only a response to uni-polarity, and a mechanism with which to allow France and Europe to take independent military action in the context of U.S. disinterest, in addition to strengthening the Atlantic Alliance and exerting greater influence within the U.S. by strengthening NATO. ${ }^{221}$ It was also a means with which to ensure French influence within its regional milieu.

By early 1994 the doctrine of 'national sanctuary' left France increasingly isolated in a critical policy area in European integration that could provide a forum for France to stake out a pace-setting role. This reflects long-standing French concerns about relative power within the European Union and attempts to exert leadership and influence in European Defense Cooperation. ${ }^{222}$ As German power and influence within the EU increased during the $1990 \mathrm{~s}$, though its agenda-setting in creating a 'monetary Europe' (EMU), so the French under Balladur and Chirac sought to revive efforts (that can be traced back to the 1963 Elysee Treaty on Franco-German cooperation) to balance German increasing influence within the EU through monetary policy by carving out a lead role in shaping 'Defense Europe'. ${ }^{223}$ This also helps explain the nature of post-Cold War patterns of high-technology capability investment in France - in support of an autonomous French and European military capability and the routing of its response to the US-led RMA through ESDP and the 'Europeanization' of the French defense industrial sector during the 1990 s. $^{224}$

Hence although the 'Europeanization' agenda and the Saint Malo Initiative allowed Chirac to bind the French left-wing to 'third-order' reform 'executive autonomy'

\footnotetext{
${ }^{220}$ Geoffrey Edwards, "Is There a Security Culture in an Enlarged European Union?" The International Spectator 41, no. 3 (summer 2006): 12.

${ }^{221}$ Press-Barnathan, "Managing the Hegemon: NATO Under Unipolarity," 304; Brenner, "The CFSP Factor: A Comparison of United States and French Strategies," 198-99; Jones, The Rise of European Security Cooperation, 214; Posen, "The European Security and Defence Policy: Response to Unipolarity," 167. As Howorth highlights, France has not only sought to embed its defense policy within ESDP, but has also been a key contributor to NATO missions during the post-Cold War period. France also took a lead role in developing the NRF in order to ensure that NATO and ESDP are 'mutually reinforcing'; Howorth, Security and Defence in the European Union, 45.

${ }^{222}$ See "Balladur Sets Kohl Meeting and Orders Cabinet Frugality," International Herald Tribune, 1 April 1994. See also Brenner, "The CFSP Factor: A Comparison of United States and French Strategies", 198; Menon, "From Independence to Cooperation: France, NATO and European Security," 22.

${ }^{223}$ Jolyon Howorth, "French Defence Reforms: National Tactics for a European Strategy?" in Brassey's Defence Yearbook 1998, (London: Brassey's, 1998), 130-151; Menon, "From Independence to Cooperation: France, NATO and European Security," 27.

${ }^{224}$ Including the promotion of Galileo as a European alternative to the US Global Positioning System (GPS), ensuring that France is not reliant on GPS for mid-course guidance updates of its Scalp cruise missile system; the development of Stealth technology systems with Germany and Sweden and the Helios I and II satellite systems; Sloan, The Revolution in Military Affairs: The Implications for Canada and NATO, 71. See also Lungu, "The US Military-Technological Revolution and the 'Europeanization' of the French Industrial Sector During the 1990s," 58-63; Sperling, "Capabilities Traps and Gaps: Symptom or Cause of a Troubled Trans-Atlantic Relationship?" 457; Rachel Utley, The French Defence Debate: Consensus and Continuity in the Mitterrand Era (London: Macmillan, 2000), 185.
} 
ensured policy leaders could focus, not on the domestic political ramifications of 'allied cooperation' (a more pronounced feature of policy leadership by German Defense Ministers), but on the 'national interest' and convergence with regional and systemic imperatives. 225

The French case highlights once more that neither 'culture' nor 'international structure' can fully explain policy convergence and divergence. Whilst the changing distribution of capabilities forms the decisive causal variable, domestic power relationships - 'executive autonomy' - is the central intervening unit-level variable determining the overall temporal location of French reform (1994-96).

\section{The UK: Constraint and Incentives - 'Brokerage to Facilitate Innovation'}

Britain's initial responses to the post-Cold War security environment, the 1990 'Options for Change' and 1993 'Statement on Defense Estimates', were piecemeal and evolutionary outlining only 'first order' changes to the 'settings' of the objectives and instruments of policy. ${ }^{226}$ It was not until the 1997 Labour Government that 'third-order' reform was initiated in the 1998 Strategic Defense Review (SDR). In contrast to the military's Cold War role (territorial and alliance defense and continental European strategy of high-intensity conflict with Soviet troops on the German plain), the Review outlined a wide scope of defense missions: peace-support and humanitarian operations and the prevention and diffusion of crises within and outside NATO's geographical scope. ${ }^{227}$ The SDR called not only for shifts in emphasis in existing defense missions, but also created a new role for the British military, 'defense diplomacy'. ${ }^{228}$ As Thornton states: 'The changes introduced, were so fundamental as to question the role of the British Army: did it exist to protect the power of the state, or did British soldiers now have the primary role of humanitarian diplomats in uniform?'.229

In the light of these changing objectives the SDR also proposed significant structural reform. The Conservatives had downsized the armed forces from 306,000 to 226,000; hence the Review did not involve large-scale reductions. ${ }^{230}$ Instead it reorganized the military to permit one full-scale, or two small-scale deployments. Crucially, the SDR institutionalized the Joint Rapid Deployment Force set up by the Conservatives in 1996, creating the Joint Rapid Reaction Force, structured around Navy, Air and Infantry assets, permitting the swift expeditionary deployment of low-high intensity British military power, providing a focal point for capability investment,

\footnotetext{
${ }^{225}$ Rynning, "Shaping Military Doctrine in France: Decisionmakers Between International Power and Domestic Interests," 113.

${ }^{226}$ Mary Kaldor, "Rethinking British Defence Policy and Its Economic Implications," Sussex European Institute Working Paper (1995): 48-49. The 1993 Statement on Defense Estimates prioritized territorial and alliance defense as the core objective of the armed forces. 'Out of area' crisis-reaction/prevention and humanitarian missions in support of the UN were afforded the lowest priority. Andrew Dorman, "Reconciling Britain to Europe in the Next Millennium: The Evolution of British Defence Policy in the post-Cold War Era," Defence Analysis 17, no.2 (summer 2001): 192.

${ }^{227}$ Sloan, The Revolution in Military Affairs: The Implications for Canada and NATO, 58.

${ }^{228}$ Forster, Armed Forces and Society in Europe, 50-51.

${ }^{229}$ Thornton, "A Welcome Revolution? The British Army and the Changes of the Strategic Defence Review," 39.

${ }^{230}$ Sloan, The Revolution in Military Affairs: The Implications for Canada and NATO, 61.
} 
accompanied by the creation of several other joint organizations. ${ }^{231}$ The army was restructured from six regiments into six mobile brigades, divided into two war-fighting divisions, increasing flexibility, mobility and sustainability on operation. The review also initiated investment in high-technology capabilities in order to permit network-enabled warfare, augmenting battlespace awareness and control capabilities and using Stealth technology, developed in conjunction with the U.S., to facilitate power projection. ${ }^{232}$

The 1999 Kosovo War demonstrated deficits in strategic lift capabilities, precision bombing and tactical communications, whilst operations in Afghanistan and Sierra Leone also highlighted the requirement for lighter forces and an explicit focus on the threats posed by 'failed states', international terrorism and the proliferation of WMD. Accordingly the 2002 'New Chapter' (a 'mini-review' of the armed forces) and 2004 Defense White Paper, 'Delivering Security in a Changing World' outlined additional changes to 'settings' of the policy instrument, to provide expeditionary forces capable of sustaining three small- and medium-scale European-led operations or one large-scale operation, conducted with the U.S..

Cultural approaches posit that what at first appears 'radical', 'third-order' change to the objectives and instruments of British armed forces resonated with deeplyembedded norms within the British military. ${ }^{233}$ Convergence with systemic imperatives did not challenge the Defense Ministry's embedded 'logic of appropriateness' and UK 'national security culture', as the military's Cold War function had been grafted onto an understanding of the role of the military that allowed smooth adaptation to the SDR's Baseline. The military's historical task in building and maintaining empire developed a conception of the role of the army as fighting small wars outside Europe, the perception of 'war as jape' and a 'distaste for inactivity' - the military had therefore retained its 'colonial focus' throughout the 1970 s and 80 s. $^{234}$

These embedded norms help explain why although reforms to force structures were dependent upon internal MoD expertise, they reflected the objectives set out in the SDR's baseline. ${ }^{235}$ This view is also supported by Miskimmon, who emphasizes not only the role of institutionally-embedded norms, but also those rooted in British society: 'The UK's colonial past, coupled with its institutional-embedding in the international community, has created a sense of responsibility and global outlook, in the minds of the British public and political elite regarding the UK's international responsibilities for peacekeeping and crisis-management'. ${ }^{236}$ Hence new security challenges and policy instruments were not objective, but were instead identified by their resonance with inheritance from the past: 'the army had old wine that flowed well into the new

\footnotetext{
${ }^{231}$ Including a joint helicopter command, joint army air-force ground based air defense organization and a chief of defense logistics. King, "Towards a Transnational Europe: The Case of the Armed Forces," 325; Sloan, The Revolution in Military Affairs: The Implications for Canada and NATO, 60.

${ }^{232}$ Sperling, "Capabilities Traps and Gaps: Symptom or Cause of a Troubled Trans-Atlantic Relationship?" 257; Sloan, The Revolution in Military Affairs: The Implications for Canada and NATO, 57.

${ }^{233}$ Thornton, "A Welcome Revolution? The British Army and the Changes of the Strategic Defence Review," 38-62.

${ }^{234}$ Thornton, "A Welcome Revolution? The British Army and the Changes of the Strategic Defence Review," 21-46.

${ }^{235}$ Colin McInnes, "Labour's Strategic Defence Review," International Affairs 74, no.4 (winter, 1998): 832.

${ }^{236}$ Miskimmon, "Continuity in the Face of Upheaval: British Strategic Culture and the Blair Government," 95 .
} 
bottles'. 237 Such accounts overlaps with the arguments of 'externalist' securitization theorists, who argue that successful speech acts must resonate with this underlying social context, for the speech act is 'historically intertextual and translates past meaning structures into the present'. ${ }^{238}$ However, closer attention to domestic material power relationships provides a stronger account of the process and outcome of reform.

The unitary state and centralization of power in the British core executive leads to a comparatively low salience of local elections, providing a sustained 'window of opportunity' between parliamentary elections to implement reform, minimizing the political impact of base closures consequent upon military restructuring. In addition, the links between social and defense policy subsystems are relatively weak in the UK, as the abolition of conscription in 1962 ensured there was no system of 'community service' providing cheap labor for the British social system.

However, although these material power relationships grant the core executive a high level of autonomy in the implementation of reform, the formal powers of the core executive in defense policy are not as distinct as in France, where power is concentrated in the hands of the President. The lack of a written constitution makes it more difficult to identify the 'formal' competencies of the core executive in defense policy. At the same time post-war UK defense policy has largely been characterized by bipartisan consensus, apart from the Labour Party's position on nuclear weapons during the 1980s. ${ }^{239}$

The evolutionary approach that characterized military reform during early-mid 90s under the Major administration was a reflection of the particularly 'murky' flux and uncertainty that characterized the initial international post-Cold War security environment: 'a defense review could be rapidly overtaken by events'. ${ }^{240}$ Although postCold War strategic imperatives became increasingly clear in the mid-90s following the 1991 Gulf War and conflict in the former Yugoslavia, this coincided with a reduction of 'executive autonomy' for the Conservatives in the context of internal party disunity over Europe that ruled out innovation on institutional venues and impending parliamentary elections in which defense was not a key issue.

The 1997 Labour Government, buoyed by a large parliamentary majority, was well-placed to engage in strategic innovation and saw in the SDR an opportunity to stake out an image as forward-thinking party in area in which it traditionally lacked an image of competence. ${ }^{241}$ However, Defense Secretary George Robertson played the role of

\footnotetext{
237 Thornton, "A Welcome Revolution? The British Army and the Changes of the Strategic Defence Review," 57. Kier's focus on organizational culture and civil-military relations would lead us to the conclusion that the smooth response to changing threats and opportunities at the international level is more a reflection of British civil-military relations and political consensus on the domestic role of the armed forces, than of the broader 'national security culture'.

${ }^{238}$ Stritzel, "Towards a Theory of Securitization: Copenhagen and Beyond," 375.

239 Andrew Dorman, "Britain and Its Armed Forces Today," The Political Quarterly 78, no.2 (spring 2007): 320 .

${ }^{240}$ See McInnes, “Labour's Strategic Defence Review,” 824. See also Kaldor, "Rethinking British Defence Policy and Its Economic Implications," 49.

${ }^{241}$ Conservative opposition to Labour's reform proposals was mitigated by the Tory legacy of cuts to the defense budget and the internal disarray within the Conservative Party following their emphatic defeat in 1997. Labour's large parliamentary majority strengthened the competencies of the core executive in defense policy vis-à-vis the House of Commons Parliamentary Select Committee on Defense. Rob Dover, "The Prime Minister and the Core Executive: A Liberal Intergovernmentalist Reading of UK Defence
} 
'policy broker'. In contrast to Chirac's marginalization of opposition through the Commaunité Stratégique, strategic innovation in Britain was consensual, with several summer seminars and appointment of an expert group to summarize the conclusions. ${ }^{242}$

This 'brokerage' role in strategic innovation was a result of two factors. Firstly, following Labour's defection from the tradition of bipartisan consensus on the issue of nuclear weapons in the 1980s (identified as an electoral mistake by New Labour Politicians) Prime Minister Tony Blair and Defense Minister George Robertson were keen to 'bind-in' the Conservative opposition and create an image of competence. ${ }^{243}$ Secondly, Labour wished to open up the decision-making process to input from the Foreign Office, in order to ensure that the SDR's 'baseline' would reflect Labour's 'internationalist' Foreign Policy. Accordingly, Foreign Minister Robin Cook chaired the three summer seminars with Robertson. This reflected 'brokerage to facilitate entrepreneurship'. ${ }^{244}$

Unlike France, where 'executive autonomy' permitted a top-down leadership style by President Chirac, but necessitated 'institutional protection' in the form of the French Defense Ministry's SAD, such 'institutional protection' was not provided in the UK, using existing structures and in-house staff, instead of establishing a separate review team. ${ }^{245}$ Institutional protection was unnecessary as the consensual bi-partisan approach to 'strategic innovation' acted to imbue the SDR's emphasis upon new security risks and strategic mobility with sufficient gravitas to leave the process of reforms to the policy instrument in the hands of the Defense Ministry. Additionally, there was widespread support within the Ministry for radical doctrinal and structural change, which was viewed as an opportunity to strike an appropriate balance between the combat 'teeth' and support 'tail' of the military after Conservative reductions in logistical support. ${ }^{246}$ Hence 'executive autonomy' incentivized 'strategic leadership' that facilitated the embrace of doctrinal and structural reform - the emphasis upon 'defense diplomacy' and the development of globally deployable forces, designed for low-high intensity tasks.

The SDR was accompanied by strong strategic leadership on 'allied cooperation'. Both Blair and Robertson used NATO and the trans-Atlantic relationship as mechanisms within which to frame and embed the new role and structure of the military. Whilst Robertson outlined radical reform, he also emphasized Labour's commitment to NATO as the key institution of British and European Security and framed military reform as a means with which to renew the Atlantic Alliance and ensure U.S. engagement in Europe, helping to bind the Conservatives to the reform agenda. ${ }^{247}$

Policy Formulation 1997-2000," British Journal of Politics and International Relations 7, no.4 (winter 2005): 516.

${ }^{242}$ Strategic Defence Review, Essay 1, Point 19, MOD, 1998.

243 Malcolm Chalmers, "Bombs Away? Britain and Nuclear Weapons under New Labour," Security Dialogue 30, no. 1 (1999): 62; McInnes, "Labour's Strategic Defence Review," 827-28.

${ }^{244}$ Dyson, "German Military Reform 1998-2004: Leadership and the Triumph of Domestic Constraint Over International Opportunity," 374.

${ }^{245}$ Strategic Defence Review, Essay 1, (Ministry of Defence, 1998).

246 Dover, "The Prime Minister and the Core Executive: A Liberal Intergovernmentalist Reading of UK Defence Policy Formulation 1997-2000," 515-16.

247 Andrew Dorman, "Reconciling Britain to Europe in the Next Millennium: The Evolution of British Defence Policy in the post-Cold War Era," Defence Analysis 17, no.2 (spring, 2001): 195. 
Whilst British armed forces reform is a case of 'third-order' change - to the objectives and instruments of defense policy - this has not been accompanied by a shift of institutional forum. Despite playing an important role in the development of intergovernmental initiatives such as the 1998 Saint Malo Accord, 1999 Helsinki Headline Goals and 2003 European Security Strategy (ESS) and an incremental shift towards the embedding of British defense policy within ESDP, UK defense and security policy remains firmly anchored within NATO. ${ }^{248}$ Although the 2004 White Paper contains five references to ESDP, it only once refers to ESDP without 'ring fencing' this through reference to NATO or the U.S.. ${ }^{249}$

Nevertheless, the December 1998 Saint Malo Accord, 2002 Helsinki Headline Goals and 2003 ESS represent a series of important, albeit incremental, steps towards the embedding of British defense policy within ESDP and a recognition that Europe has to be capable of autonomous military action in cases of U.S. disinterest. ${ }^{250}$ Rather than the first signs of 'soft' balancing behavior by the British, ESDP represents an mechanism with which the UK can gain greater influence within the U.S. and strengthen the Atlantic Alliance by developing European military capabilities that would not only be of use to ESDP, but also to NATO. ${ }^{251}$

According to normative approaches, British 'Atlanticism' and preference for routing defense cooperation through NATO represents the culturally-bounded and institutionally-embedded lessons drawn from the Second World War and Suez about the utility of the U.S. security guarantee in helping the UK 'punch above its weight'. ${ }^{252}$ The sequencing and temporal location of changes to the 'settings' of British institutional forums (following changes to the objectives and instruments of policy) is a result of the depth of Atlanticism in British security culture, acting as a powerful constraint on the willingness of British policy makers to sanction any policy that might threaten the Atlantic Alliance. ${ }^{253}$

However, neoclassical realism provides a more nuanced explanation of the temporality of changes to the institutional venues of British defence policy. The temporal

${ }^{248}$ Dorman, "Reconciling Britain to Europe in the Next Millennium: The Evolution of British Defence Policy in the post-Cold War Era," 187-202; Dover, “"The Prime Minister and the Core Executive: A Liberal Intergovernmentalist Reading of UK Defence Policy Formulation 1997-2000," 508-21; Tim Dunne, "When the Shooting Starts: Atlanticism in British Security Policy," International Affairs 80, no.5 (autumn, 2004): 908; Smith, "Britain: Balancing Instinctive Atlanticism," 447-69.

${ }^{249}$ Edwards, "Is There a Security Culture in an Enlarged European Union?" 12.

${ }^{250}$ Dorman, "Reconciling Britain to Europe in the Next Millennium: The Evolution of British Defence Policy in the post-Cold War Era," 187-88; Dover, “"The Prime Minister and the Core Executive: A Liberal Intergovernmentalist Reading of UK Defence Policy Formulation 1997-2000, 508-21; Jones, The Rise of European Security Cooperation, 55.

${ }^{251}$ Dorman, "Reconciling Britain to Europe in the Next Millennium: The Evolution of British Defence Policy in the post-Cold War Era," 195; Howorth, Security and Defence Policy in the European Union, 53; Rynning, NATO Renewed: The Power and Purpose of Trans-Atlantic Cooperation, 91; Sloan, The Revolution in Military Affairs: Implications for Canada and NATO, 56.

${ }^{252}$ Miskimmon, "Continuity in the Face of Upheaval: British Strategic Culture and the Blair Government," 90; Smith "Balancing Instinctive Atlanticism," 447-69; William Wallace, "British Foreign Policy after the Cold War", International Affairs 68, no.3 (summer 1992): 423-442.

${ }^{253}$ Miskimmon, "Continuity in the Face of Upheaval: British Strategic Culture and the Blair Government," 90; Michael Quinlan, European Defence Cooperation: Asset or Threat to NATO? (Washington: Woodrow Wilson Centre Press, 2001), 36. 
location of the incremental shift towards the development of a stronger European military capability (the Saint Malo Initiative of October 1998) is the product of the clarity of the implications of uni-polarity for the institutional forums of British defense policy in midlate $1998 .^{254}$ First-order change was spurred by the fear of 'abandonment' by the U.S. in the run-up to the 1999 Kosovo conflict, which brought home to British policy makers the uncertainties of the U.S. security guarantee. ${ }^{255}$ A secondary, though important, factor determining temporality was the identification of ESDP by Blair as a means with which to help remedy Britain's increasing lack of influence within the EU, countering German influence though EMU, compensating for the British decision not to join in the first wave, and for early French leadership on ESDP. ${ }^{256}$ These systemic imperatives combined with high levels of executive autonomy to determine the quick pace of changes to the 'settings' of British policy on institutional venues. ${ }^{257}$

Hence in contrast to Germany and in line with France, 'executive autonomy' has facilitated a stronger focus by policy leaders on the 'national interest', rather than the domestic political ramifications of 'allied cooperation'. ${ }^{258}$ The overall pace of UK reform (14 months), which cultural approaches have difficulty in explaining, reflects not only the logistical complexity of the review process, but also the configuration of domestic power relationships and linkages between budgetary and defense policy, namely the Treasury's wish that the SDR did not precede the Comprehensive Spending Review. ${ }^{259}$

254 Dorman, "Reconciling Britain to Europe in the Next Millennium: The Evolution of British Defence Policy in the post-Cold War Era," 195-96; Rynning, NATO Renewed: The Power and Purpose of TransAtlantic Cooperation, 91.

${ }^{255}$ Howorth, Security and Defence Policy in the European Union, 53.

256 Dorman, "Reconciling Britain to Europe in the Next Millennium: The Evolution of British Defence Policy in the post-Cold War Era," 194-95; Dover, "“The Prime Minister and the Core Executive: A Liberal Intergovernmentalist Reading of UK Defence Policy Formulation 1997-2000," 511-12.

${ }^{257}$ Press-Barnathan, "Managing The Hegemon: NATO Under Unipolarity," 271-309; Stuart Croft, Andrew Dorman, Wyn Rees and Matthew Uttley, Britain and Defence 1945-2000: A Policy Re-Evaluation (Essex: Pearson, 2001), 63; Dorman, "Reconciling Britain to Europe in the Next Millennium: The Evolution of British Defence Policy in the post-Cold War Era," 194; Dover, "The Prime Minister and the Core Executive: A Liberal Intergovernmentalist Reading of UK Defence Policy Formulation 1997-2000," 513.

${ }^{258}$ As Dover highlights, the pace (6 months) of the incremental changes to the "settings' of British policy on institutional venues in 1998 was facilitated by a high level of executive autonomy - a concentration of power in the core executive (notably Blair, but also Robertson) and a lack of domestic opposition from within the defense ministry or from other actors within the broader defense and security policy subsystem. First-order change to the 'settings' of policy did not require the bipartisan 'brokerage' that had accompanied the 'third-order' change of the SDR. Dover, "The Prime Minister and the Core Executive: A Liberal Intergovernmentalist Reading of UK Defence Policy Formulation 1997-2000,” 511-515.

259 Blair and Robertson had originally intended the reform process to last only 6 months. McInnes, “Labour's Strategic Defence Review,” 829. 


\section{Table 2: Neoclassical Realist and Cultural Explanations of the Temporality of Military Reform}

\begin{tabular}{|c|c|c|c|}
\hline & Britain & France & Germany \\
\hline $\begin{array}{l}\text { Cultural } \\
\text { Explanations } \\
\text { of the } \\
\text { Temporality of } \\
\text { Reform }\end{array}$ & $\begin{array}{l}\text { Location: } 1997-98 \text { shift to crisis- } \\
\text { management and restructuring } \\
\text { facilitated by resonance with } \\
\text { institutionally/societally } \\
\text { embedded beliefs concerning role } \\
\text { of military in fighting small wars } \\
\text { of varying intensity outside } \\
\text { Europe during the colonial era. } \\
\text { Given such resonance the late } \\
\text { location of convergence when } \\
\text { compared to France is perplexing. } \\
\text { Pace: } 14 \text { month reform process } \\
\text { surprising given resonance of } \\
\text { changes with British security } \\
\text { culture. } \\
\text { Sequencing: Reform to } \\
\text { objectives, instruments followed } \\
\text { by incremental Europeanization, } \\
\text { consequent upon depth of } \\
\text { Atlanticism within British } \\
\text { security culture. }\end{array}$ & $\begin{array}{l}\text { Location: } 1994-96 \text { shift to crisis- } \\
\text { management/professional forces } \\
\text { due to roles of Balladur and Chirac } \\
\text { as 'norm entrepreneurs' overcoming } \\
\text { path dependent commitment to } \\
\text { conscription. } \\
\text { Pace: } 32 \text { month reform consequent } \\
\text { upon path dependent commitment } \\
\text { to conscription. However, this fails } \\
\text { to capture domestic material factors } \\
\text { restricting executive autonomy. } \\
\text { Sequencing: Reform to objectives } \\
\text { and institutional forums preceding } \\
\text { reform to instruments due to } \\
\text { Balladur/Chirac's role in identifying } \\
\text { ESDP with idea of France as 'third } \\
\text { force' and 'Europeanization of } \\
\text { French Exceptionalism'; impact of } \\
\text { path dependent commitment to } \\
\text { conscription. }\end{array}$ & $\begin{array}{l}\text { Location: } 2003 \text { shift to crisis- } \\
\text { management due to deeply } \\
\text { embedded culture of anti- } \\
\text { militarism, resistant to change. } \\
\text { Pace: Path dependent commitment } \\
\text { to conscription and citizen in } \\
\text { uniform'. Laggard role of Defense } \\
\text { Ministry on ESDP due to post-war } \\
\text { socialization processes, leading to } \\
\text { Atlanticized institutional culture. } \\
\text { Difficulties in explaining } 6 \text { month } \\
\text { reform to objectives, given } \\
\text { societally/institutionally embedded } \\
\text { norms concerning objectives and } \\
\text { instruments of German defense } \\
\text { policy. } \\
\text { Sequencing: Path dependency and } \\
\text { impact of German security culture } \\
\text { leading to stasis on policy } \\
\text { instruments. }\end{array}$ \\
\hline $\begin{array}{l}\text { Neoclassical } \\
\text { Realist } \\
\text { Explanations } \\
\text { of the } \\
\text { Temporality of } \\
\text { Reform }\end{array}$ & $\begin{array}{l}\text { Location: Opacity of systemic } \\
\text { power shift in early 90s; } \\
\text { reduction in executive autonomy } \\
\text { for Conservatives in mid-90s due } \\
\text { to internal disunity and } \\
\text { forthcoming } 1997 \text { Parliamentary } \\
\text { elections. High executive } \\
\text { autonomy enjoyed by Labour } \\
\text { Government in May } 1997 \\
\text { (unitary state, high parliamentary } \\
\text { majority and weak links between } \\
\text { defense, social and budgetary } \\
\text { policy subsystems). } \\
\text { Pace: Configuration of domestic } \\
\text { power relationships; linkages } \\
\text { between budgetary and defense } \\
\text { policy -Treasury's wish that SDR } \\
\text { did not precede Comprehensive } \\
\text { Spending Review. } \\
\text { Sequencing: Incremental shift } \\
\text { towards ESDP following SDR } \\
\text { due to realization of threat of } \\
\text { abandonment by U.S. in late } \\
\text { 1998. }\end{array}$ & $\begin{array}{l}\text { Location: High executive } \\
\text { autonomy and 'state power' due to } \\
\text { nature of Defense Policy as } \\
\text { 'reserved domain' of the President, } \\
\text { unitary state and ability of President } \\
\text { to implement base closures and } \\
\text { weaker links between social, } \\
\text { defense and budgetary policy } \\
\text { subsystems. } \\
\text { Pace: Nature of military policy as } \\
\text { 'shared domain' during cohabitation } \\
\text { (1993-95) and lack of support from } \\
\text { Finance Ministry for reform to } \\
\text { policy instruments during } \\
\text { cohabitation; impact of forthcoming } \\
\text { Presidential elections in May 1995. } \\
\text { Sequencing: Reform to institutional } \\
\text { forums preceding objectives and } \\
\text { instruments due to French focus on } \\
\text { balancing German power through } \\
\text { EMU by lead role on 'defense } \\
\text { Europe'; impact of cohabitation } \\
\text { upon reforms to policy instruments. }\end{array}$ & $\begin{array}{l}\text { Location: Low executive autonomy } \\
\text { and 'state power' due to dispersal of } \\
\text { formal competencies on defense } \\
\text { policy within core executive; } \\
\text { federal state leading to heightened } \\
\text { sensitivity to politics of base } \\
\text { closures; interlinked social, defense } \\
\text { and budgetary policy subsystems } \\
\text { due to system of Zivildienst. } \\
\text { 'Culture' not causal but a tool in } \\
\text { temporal and political management } \\
\text { of reform. } \\
\text { Pace: } 6 \text { month reform (May- } \\
\text { October } 2003 \text { ) due to SPD concern } \\
\text { with implementing base closures } \\
\text { consequent upon the downsizing of } \\
\text { the armed forces by } 35,000 \text { troops } \\
\text { in advance of the next Federal } \\
\text { elections and to close down } \\
\text { possibility for macro-political } \\
\text { debate on conscription. } \\
\text { Sequencing: Temporal } \\
\text { manipulation of reform incentivized } \\
\text { by low executive autonomy. }\end{array}$ \\
\hline
\end{tabular}




\section{Conclusions}

Neo-realism provides only a partial explanation of convergence and divergence in military reform. Through its focus on role of the competitive nature of the international system in forcing states to organize for war as effectively as possible, neo-realism neglects the extent to which domestic power relationships can incentivize a short-medium term preoccupation with domestic political interests rather than 'systemic imperatives', leading to the domestic political and temporal management of reform.

Although the strength of the shift in the systemic distribution of capabilities following the end of the Cold War is driving Britain, France and Germany towards convergence in the instruments, objectives and institutional forums of defense policy, the analysis presented also demonstrates how the policy implications of systemic power shifts are not always immediately clear to policy makers in the period following a significant shift in the systemic distribution of material capabilities. The particular opacity of systemic imperatives during such periods of flux forms an important initial intervening variable that impacts upon the temporality of reform over the short-term. ${ }^{260}$

However, 'state power', impacting upon the ability of the core executive to 'extract and direct the resources of their societies', emerges as the crucial intervening variable in explaining temporal divergence. ${ }^{261}$ The article has analyzed in particular, the impact of the institutional structure of the state and domestic material power relations on 'state power'. ${ }^{262}$ It finds that 'executive autonomy' in the sphere of defense policy - a determinant of the degree of centralization/decentralization of the state, the constitutional powers of the core executive and linkages between social, finance and defense policy subsystems - is the key intervening variable in shaping the temporality of reform. It does so by impacting upon the ability and willingness of Presidents/Prime Ministers and

\footnotetext{
${ }^{260}$ It is also important to note that whilst 'broadly similar' in material capabilities and 'external vulnerability', attention should also be paid to nuances in British. French and Germany 'external vulnerability' stemming from geographical location. Hence, as the analysis has demonstrated, French preoccupation with relative power vis-à-vis Germany impacts upon the scope and pace of change to the institutional forums of French defense policy. This helps to explain why, despite high levels of 'executive autonomy' in both the UK and France, changes to the institutional forums of their defense policies took place at divergent temporal locations (1994 and 1998 respectively).

${ }^{261}$ Rose, "Neoclassical Realism and Theories of Foreign Policy," 161.

${ }^{262}$ Taliaferro, "State Building For Future Wars: Neoclassical Realism and the Resource Extractive State," 487-91. Taliaferro also highlights the roles of nationalism and ideology as important intervening variables in determining state power. However, the inclusion of such variables within neoclassical realism runs the risk of violating the material core of realist thought, in addition to further compromising its parsimony. Instead, the analysis presented in this article suggests that it is perhaps more accurate to view culture, nationalism and ideology not so much as constraints on policy makers and as intervening variables, but as tools and resources in the hands of statesmen; albeit tools that are, at times, difficult to master. Barry, R. Posen, "Nationalism, the Mass Army and Military Power," International Security 18, no.2 (1993): 81. However, further empirical research is required is order to understand the precise role played by the variables of nationalism and ideology. On reductionism and the material core of realist thought, see Michael C. Desch, "Culture Clash: Assessing the Importance of Ideas in Security Studies," International Security 23, no.1 (summer 1998): 155-56; Jeffrey W. Legro and Andrew Moravcsik, "Is Anybody Still A Realist?" International Security 24, no.2 (autumn 1999): 28-29; 35-36; John Vasquez, "The Realist Paradigm and Degenerative Versus Progressive Research Programmes: An Appraisal of Neotraditional Research on Waltz's Balancing Proposition," The American Political Science Review 91, no. 4 (winter 1997): 899-912.
} 
Defense Ministers to undertake 'strategic innovation' and provide 'institutional protection' to new objectives and instruments of defense policy. The extent of 'executive autonomy' in defense policy also informs the degree to which 'allied cooperation' through NATO/the EU will reflect the 'domestic' or 'national' interest over the shortmedium-term.

Although we must look to structure ('executive autonomy') rather than agency as the root-cause unit-level variable that provides the incentive for the promotion of shortmedium term temporal lag with systemic imperatives, this does not fully negate the impact of specific instances of domestic reform management in determining patterns of change and continuity in military policy. ${ }^{263} \mathrm{~A}$ focus on the ability of policy leaders to successfully manage the three aspects of change - strategic innovation, institutional protection and allied cooperation - is certainly a significant factor in determining the temporality of military reform. ${ }^{264}$ This is most evident in Germany, from the mid-late $90 \mathrm{~s}$ onwards, as the inadequacies of a conscript Bundeswehr oriented towards territorial defense became increasingly evident. The ability of Rühe, Scharping and Struck to control the flow of ideas and learning within the Defense Ministry, policy subsystem and at the macropolitical level had an important impact upon the success of the promotion of 'policy 'stasis'. An analysis of the detail of strategic leadership also sheds doubt upon the utility of culturalist approaches as stand-alone explanations of policy change by drawing attention to the selective use of 'strategic culture' by policy leaders. It highlights how 'culture' is not so much a cause of action as instrumental and a tool in the domestic political and temporal management of military reform.

\footnotetext{
${ }^{263}$ Rynning, "Shaping Military Doctrine in France: Decisionmakers Between International Power and Domestic Interests," 114.

${ }^{264}$ It would be erroneous to factor out the role of individual leaders in determining state power (not least as the core executive and statesmen emerge as important actors within neoclassical realist theory). However, assessing the influence of 'first image' variables on international politics and the impact of individuals and personality on the course of history is a process fraught with difficulty and intangibility and is beyond the scope of this article. On the role of 'first-image' variables in realist theory and the difficulties of measuring the impact of individuals see Daniel L. Byman and Kenneth M. Pollack, "Let Us Now Praise Great Men: Bringing the Statesman Back In," International Security, 25, no.4 (spring 2001): 107-146; Fred I. Greenstein, "The Impact of Personality on Politics: An Attempt to Clear Away Underbrush," American Political Science Review, 61, no.3 (autumn 1967): 629-41; Daniel L. Byman, Kenneth M. Pollack and Andrew Parasiliti, "Correspondence: The First Image Reversed," International Security 26, no.2 (autumn 2001): 166-69. Resende-Santos also notes how competitive effectiveness 'may also comprise intangible factors such as skill and leadership'; Resende-Santos, Neorealism, States and the Modern Mass Army, 63.
} 